\title{
Organization of pre-Variscan basement areas at the north-Gondwanan margin
}

\author{
J.F. von Raumer • G.M. Stampfli • G. Borel • F. Bussy
}

Received: 12 May 2000 / Accepted: 24 January 2001 / Published online: 12 May 2001

\begin{abstract}
Pre-Variscan basement elements of Central Europe appear in polymetamorphic domains juxtaposed through Variscan and/or Alpine tectonic events. Consequently, nomenclatures and zonations applied to Variscan and Alpine structures, respectively, cannot be valid for pre-Variscan structures. Comparing preVariscan relics hidden in the Variscan basement areas of Central Europe, the Alps included, large parallels between the evolution of basement areas of future Avalonia and its former peri-Gondwanan eastern prolongations (e.g. Cadomia, Intra-Alpine Terrane) become evident. Their plate-tectonic evolution from the Late Proterozoic to the Late Ordovician is interpreted as a continuous Gondwana-directed evolution. Cadomian basement, late Cadomian granitoids, late Proterozoic detrital sediments and active margin settings characterize the pre-Cambrian evolution of most of the Gondwana-derived microcontinental pieces. Also the Rheic ocean, separating Avalonia from Gondwana, should have had, at its early stages, a lateral continuation in the former eastern prolongation of peri-Gondwanan microcontinents (e.g. Cadomia, Intra-Alpine Terrane). Subduction of oceanic ridge (Proto-Tethys) triggered the break-off of Avalonia, whereas in the eastern prolongation, the presence of the ridge may have triggered the amalgamation of volcanic arcs and continental ribbons with Gondwana
\end{abstract}

J.F. von Raumer (『)

Institut de Minéralogie et Pétrographie, Université Pérolles, 1700 Fribourg, Switzerland

E-mail: Juergen.vonRaumer@unifr.ch

Phone: +41-26-3008927

Fax: +41-26-3009765

G.M. Stampfli · G. Borel

Institut de Géologie, Université de Lausanne,

UNIL BFSH2 1015 Lausanne, Switzerland

F. Bussy

Institut de Minéralogie, Université de Lausanne,

UNIL BFSH2 1015 Lausanne, Switzerland
(Ordovician orogenic event). Renewed Gondwana-directed subduction led to the opening of Palaeo-Tethys.

Keywords Rheic ocean - Peri-Gondwana evolution · Pre-Variscan basement - Palaeo-Tethys .

Palaeoreconstruction · Cambro-Ordovician

\section{Introduction}

Pre-Variscan elements of Central Europe are mostly exposed as pre-Mesozoic basement areas that underwent the Variscan thermotectonic events, and occur as polymetamorphic domains which, after their respective drift and amalgamation, have been stacked and "shovelled" during Variscan (e.g. Bard 1997; Oncken 1997) and Alpine events one in front of the other to produce the present-day juxtaposition. During their large-scale accretion and strike-slip transport, many of these basement areas left behind their lithospheric roots. Consequently, in the European Variscan basement areas (Fig. 1; e.g. Iberia, Armorica, Moesia, French Massif Central, Saxothuringian and Moldanubian domains, External massifs, Penninic domain, parts of the southern Alps and the Austroalpine basement), nappe and strike-slip structures of different ages repeat elements which, initially, had a distinct pre-Variscan location, and a common evolution, comprising different steps since the Precambrian. The current nomenclatures and zonations applied to Variscan or Alpine regional structures cannot characterize the original location of pre-Variscan crustal elements and, necessarily, a new nomenclature has to be based on plate tectonic criteria considering the geotectonic evolution of these elements during the Neoproterozoic and Early Palaeozoic. As we are dealing mostly with lithostratigraphies of metamorphic areas, we try to maintain a standpoint independent of models of Variscan evolution of these areas. 


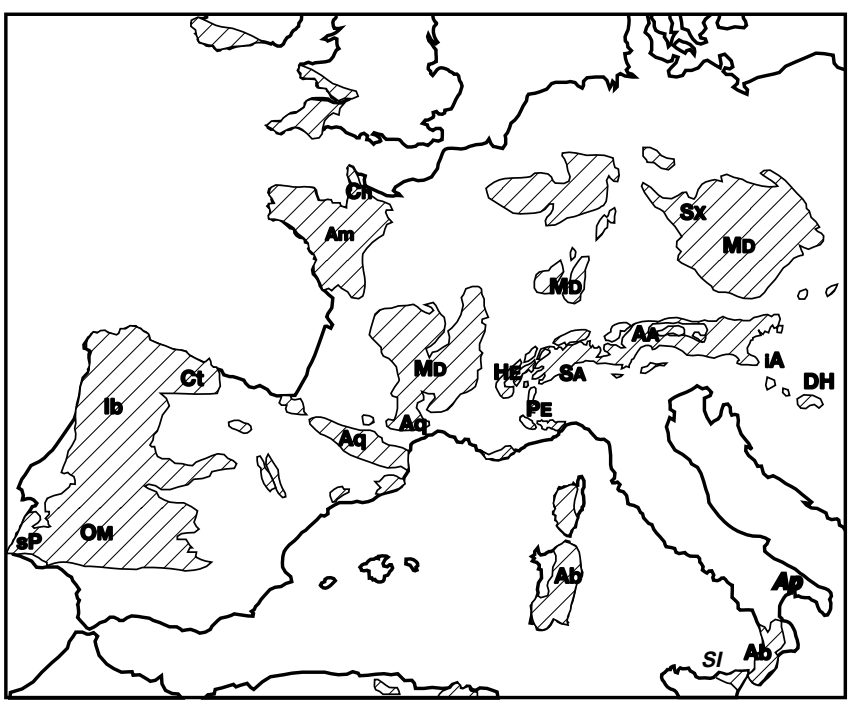

Fig. 1 Distribution of Pre-Mesozoic (Variscan and/or older) units in Europe (Zwart and Dornsiepen 1978) with indication of distinct microcontinents (see Fig. 7). $A A$ Austro-Alpine; $A b$ Alboran; $A m$ Armorica; $A p$ Apulia; $A Q$ Aquitaine; $A R$ Armorica; $C h$ Channel terrane; $C t$ Cantabria; $D H$ Dinarides-Hellenides; $H e$ Helvetic; $i A$ intra-Alpine; $I b$ Iberia; $M D$ Moldanubian; $O M$ Ossa-Morena; Or Ortegal; $P e$ Penninic; $s P$ south Portuguese; $S x$ Saxothuringian

Examples of the Early Palaeozoic evolution preserved in the Variscan mountain chain of Europe are numerous (see Dallmeyer et al. 1995; Keppie 1994; von Raumer and Neubauer 1993a, 1993b; Franke et al. 2000). Sedimentary and fossil records, as well as age determinations, show the overall presence of Neoproterozoic to Early Palaeozoic basements supposed to have evolved along the margin of Gondwana, and sharing specific structural elements and events. For the time period after the Ordovician, different platetectonic evolutions are proposed, favouring either one (Robardet et al. 1990) or two major mid-European oceanic separations (Matte 1986), or the separation of a basement assemblage ("Hun-superterrane"; Stampfli 1996, 2000). Such divergent reconstructions need to be tested, and it is the aim of this paper to discuss, from a "Gondwanan" standpoint, and independently of the Variscan structures, parallels of pre-Variscan evolution among the polymetamorphic basement areas mentioned previously.

\section{Pre-Ordovician peri-Gondwana evolution}

Among the different pre-Variscan relics preserved in the Variscan basement areas - the pre-Mesozoic Alpine basement areas included - we can distinguish distinct geodynamic settings from the Precambrian to the Ordovician, comprising Precambrian basement blocks (Cadomian/PanAfrican basement) and their sedimentary cover, formation of Late Precambrian to Cambro-Ordovician oceanic crust, volcanic arcs, and active margin remnants, and zones of amalgamation (accretion, collision) of Early Palaeozoic age.

Fig. 2 Plate tectonic re-interpretation of pre-Variscan units in the Alps. Compared with Frisch and Neubauer (1989, terminology in italic with quotation marks), all Early Palaeozoic terranes of the Alps are re-interpreted in terms of their peri-Gondwanian origin. Pieces comparable to those of the "Noric composite Terrane" are interpreted to be related to the opening of Palaeotethys. The arc volcanic "Celtic Terrane" and its counterparts in the Western Alps represent units with Early Palaeozoic metamorphism. Terranes related to the opening of Early Palaeozoic oceanic domains ("Speik Terrane") represent either contemporaneous or successor stages of Rheic ocean and/or its equivalents. Arc volcanics ("Habach Terrane") represent Early Palaeozoic active margin settings. Other signatures in the domain of the Eastern Alps, not mentioned in the explanations, refer to Variscan elements and structures (see Frisch and Neubauer, 1989). Inset General situation of the Alpine pre-Mesozoic basement terranes (black) within their present-day Variscan framework. $M C$ French Central Massif; $B M$ Bohemian Massif

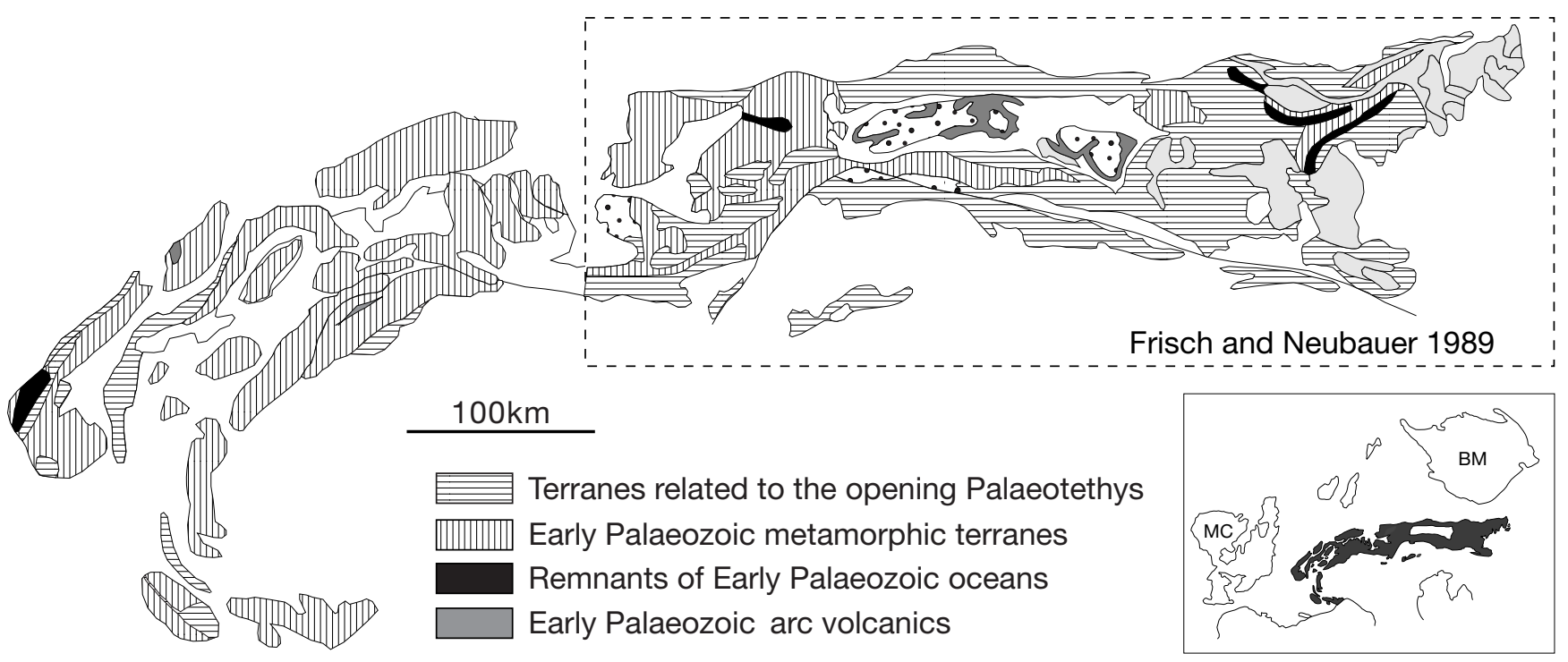


Fig. 3 Comparative time-table of tectonic and magmatic events in the different periGondwanan microcontinents

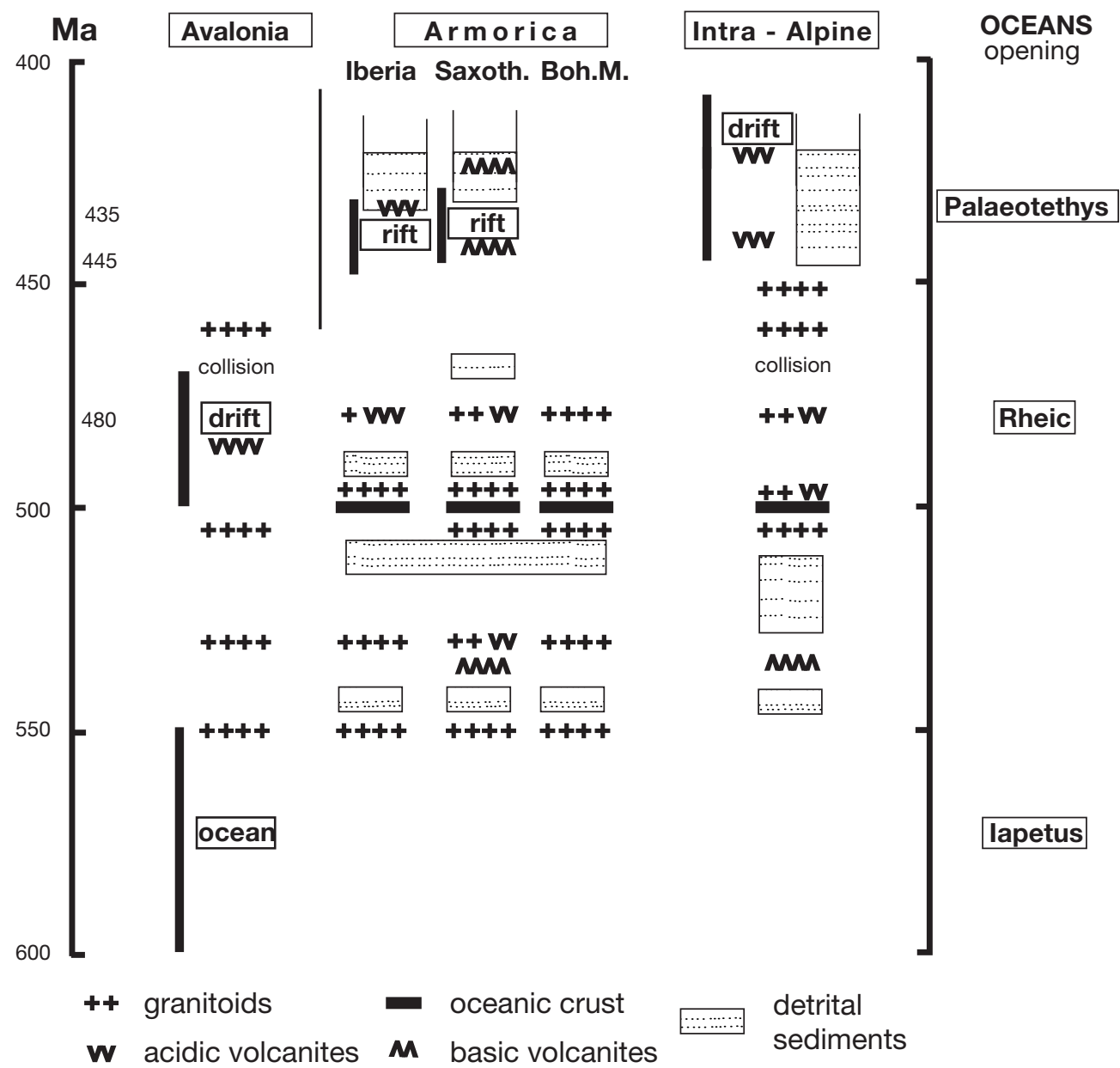

Although less evident, a comparable evolution is hidden among the basement areas in the Alps. Re-interpreting the terrane model of Frisch and Neubauer (1989) from the Eastern Alps and the corresponding lithological units (Neubauer et al. 1999) in the frame of polymetamorphic basement areas in the entire Alps (Fig. 2), we can distinguish (a) a lower Palaeozoic sedimentary cover sequence, interlayered by volcanic rocks, in this paper interpreted as units related to the opening Palaeo-Tethys (see below); and (b) units, hidden in the polymetamorphic domains, containing older, mostly Cadomian/pan-African metamorphic basement units with relics of Cambrian-Neoproterozoic magmatic arcs and/or Cambrian ophiolites, with an (not in all places) Early Palaeozoic cover sequence, either intruded by Ordovician granitoids or containing Ordovician volcanites.

Consequently, the Intra-Alpine basement areas (Helvetic, Penninic, Austroalpine, Southalpine) fit well with the pre-Variscan evolution observed in their present-day Variscan framework (Fig. 3) and, when thinking in terms of a peri-Gondwanan location, they are thought to have occupied a former eastern lateral continuation of the present-day Variscan framework (see Fig. 7; von Raumer 1998). The different pre-Silu- rian stages of evolution mentioned previously are compared using observations from the Alps as well as from Variscan basement areas in Europe.

\section{Cadomian basement}

The peri-Gondwanan microcontinents and their Cadomian elements represent successor stages of a disintegrating Neoproterozoic supercontinent. Independent of configuration (Rodinia: Hoffmann 1991, Dalziel 1992, Unrug 1997; Palaeopangaea: Piper 2000), continental dispersal led to the Cambrian formation of Gondwana (e.g. Powell et al. 1993). Rapid drift of large continents is assumed for the Neoproterozoic (Gurnis and Torsvik 1994), and an active continental margin setting is accepted for the Cadomian belt (Brown 1995; Torsvik et al. 1994), where subduction may have been related to the opening of Iapetus (Grunow et al. 1996).

Zwart and Dornsiepen (1978), Cogné and Wright (1980), and Ziegler (1984) derived pre-Variscan units from the former Proterozoic Europe-African Block, and such basement relics are assumed to be part of Avalonia (e.g. Rast and Skehan 1983; Skehan and 
Rast 1983). It is not the scope of this paper to recall the complex evolution of these oldest elements which either appear as low-grade or as polymetamorphic domains (pan-African/Cadomian orogeny), and for which the relationship between Cadomian basement areas and Neoproterozoic to Early Palaeozoic sedimentary cover have been the subject of extensive research. The general picture of small continental blocks bordering the Gondwana margin (Nance and Murphy 1994) explains best the many relationships which existed between all these pieces. Large-scale magmatic activity is documented by syn- and postorogenic granitoids or acidic volcanites in the wider framework of Gondwanan evolution (see below). Also in the Alpine domain, a distinction can be made between a Proterozoic and Archean inheritance, Late Precambrian mafic and ultramafic rocks, and relics of Precambrian-Cambrian sediments (Schaltegger and Gebauer 1999). Widely distributed across the different Alpine realms, these sediments contain detrital zircons suggesting derivation from Cadomian-pan-African and older basement units. Comparable results were obtained from detrital micas (Dallmeyer and Neubauer 1994; Dallmeyer et al. 1996a, 1996b; Handler et al. 1997; Panwitz et al. 2000). Pre-Cambrian basement is discussed for a few regions in the Western and Central Alps (Gebauer 1993), including the Gotthard area of the External domain (Gebauer et al. 1988), the Berisal Complex (Stille and Tatsumoto 1985; Zingg 1989) and Siviez-Mischabel unit (Thélin et al. 1993) of the Penninic domain, probably the "ancient basement" in the internal zones of the Western Alps (Desmons et al. 1999), the Silvretta area of the Austroalpine basement (Schaltegger et al. 1997), and in the Eastern Alps (Neubauer 1991; von Quadt 1992; Thöni 1999). Sm-Nd data (e.g. Liebetrau and Nägler 1994; Böhm 1996; Poller et al. 1997) from Cambro-Ordovician or Variscan granitoids closely match values observed in the Bohemian Massif (Hegner and Kröner 2000), in NW Iberia (Fernández Suárez et al. 1998) and from West Avalonia (Nance and Murphy 1996). Findings of Cadomian ages in the Pontides (Üstaömer 1999) would allow extension of this domain eastward maybe up to the Caucasus.

\section{Early Palaeozoic sedimentary troughs-oceanic settings}

Subsidence analysis shows the large-scale opening of early Palaeozoic sedimentary basins for Laurentia and western Gondwana (Williams 1997), and contemporaneous events are registered in the Armorican Massif (Paris and Robardet 1990; Robardet et al. 1994), and in the Ossa Morena domain (Liñan and Quesada 1990). In an Early Cambrian reconstruction (McKerrow et al. 1992), Archaeocyathan assemblages indicate a climate-sensitive palaeogeographic location within $30^{\circ}$ of the equator. Regular fracture patterns determine the direction of intra-continental sedimentary troughs (Courjault-Radé et al. 1992), and delimit large areas with deposits of continental-margin environment in the Gondwana platform during the Cambrian. In fact, the most important lithology, locally highly metamorphosed association of metagreywackes, metapelites, a few quartzites, carbonates, and metavolcanic interlayers, is well known in the Central Iberian domain, and in the Montagne Noire area, but also from several Alpine domains (e.g. External Massifs, Southern Alps, von Raumer 1998; ancient basement areas of the Penninic domain, Desmons et al. 1999), or the Pyrenees (Laumonier 1998), and has astonishing parallels with fossil-bearing, Neoproterozoic to Cambrian lithostratigraphies from the Saxothuringian domain (e.g. Buschmann et al. 1995), with several localities around the Mediterranean Sea (Sdzuy et al. 1999), or well-preserved examples observed in the Anti-Atlas mountain chain of Morocco; however, in addition to the aforementioned parallels also discrepancies exist. Comparable lithologies may remain undiscovered in the polymetamorphic areas of the Variscan mountain chain, as the high plasticity of marbles during metamorphic overprint may reduce considerably original limestone occurrences, which may dissappear completely during metamorphic evolution. On the other hand, a specific palaeogeographic configuration may influence carbonate distribution. They may have been deposited on the Gondwana platform, they may have been resedimented as reduced detrital carbonate layers near a rift shoulder (e.g. Freyer and Suhr 1987), and may have been replaced by contemporaneous clastic sequences in the domain of Cambrian rift zones. Extensive Ordovician areas of similar sedimentary facies at the Gondwana shelf (Noblet and Lefort 1990; Robardet 1996) may explain comparable facies evolution in the Saxothuringian areas (Linnemann and Buschmann 1995), in the Armorican massif (Paris et al. 1999), and regions included in the polymetamorphic domains (e.g. Mingram 1996, 1998). Fossil findings confirm the presence of lower Palaeozoic metasediments even in Variscan high grade metamorphic rocks (e.g. Schwarzwald, Hanel et al. 1999) and in low-grade Alpine metamorphic series from the Southern Alps (Ordovician, Gansser and Pantic 1988) and Eastern Alps (Arenig, Grauwackenzone; Reitz and Höll 1991).

It is tempting to correlate the Cambrian period of rifting (see above) and the distribution of relics of oceanic domains. From the Late Precambrian to the Ordovician different generations of oceanic domains were involved in the plate-tectonic evolution. Late Precambrian oceanic crust and Cambrian volcanic arcs (Haydoutov 1989; von Quadt 1992; Schaltegger et al. 1997; Schaltegger and Gebauer 1999; Chen et al. 2000; Crowley et al. 2000; Fernández Suárez et al. 2000) confirm the relationship of several domains with the Neoproterozoic orogenic belt and the existence of different tectonic regimes along the Gondwana margin. Traces of what is assumed to represent the former 
time equivalents of the Rheic ocean are found in the Cambrian mafic-ultramafic complexes such as the Chamrousse ophiolite of the Alps (Ménot 1987) and the Vesser zone of the Saxothuringian domain $(\mathrm{H}$. Kemnitz et al., submitted), and can be followed through different metamorphic complexes in the Bohemian massif (Finger et al. 1998; Mingram et al. 1998; Stipska et al. 1998; Winchester et al. 1998; Kröner et al. 2000). Relics may occur in the French Central Massif (Pin 1991), and exist in the Iberian basement areas (Fernández-Suárez et al. 1998; Ordoñez Casado 1998; Abati et al. 1999; Andonaegui et al. 1999), and in the northern part of Sardinia (Carmignani et al. 1994). However, it cannot be excluded that relics of Cambro-Ordovician oceanic crust may represent one or more parallel "Rheic" rifts separated by ribbons of "Cadomian" or "Avalonian-type" basement areas (microcontinents) and, additionally, metabasites partly may represent either the Ordovician-Silurian successors of the Rheic ocean or time equivalents of the Proto-Tethys.

\section{Comparing the peri-Gondwanan evolution}

From the Neoproterozoic to the Ordovician detachment of Avalonia from Gondwana, striking parallels of plate-tectonic evolution become visible (Fig. 3) between Avalonia, Armorica and the peri-Gondwanan microcontinents located farther to the east, confirming in some way the lateral alignment of the microcontinents at the Gondwana margin. The rifting period accompanying the opening of Iapetus certainly left structures on either side of the future Iapetus ocean. Such intraplate rift systems may have guided the emplacement of Precambrian/Cambrian volcanites and intrusions, and also initial formation of oceanic crust in basement areas located at the eastern prolongation of future Avalonia. A general situation of Neoproterozoic active margin at the Gondwana border (see above) is documented (e.g. Iberia: Fernández-Suárez et al. 1999; Bohemian Massif: Zulauf et al. 1999, Kröner et al. 2000; Saxothuringian domain: Linnemann et al. 2000; in the Alps: Neubauer 1991; von Quadt 1992; Schaltegger et al. 1997), and the picture of widespread late Proterozoic sediments and volcanic rocks, and the formation of Cambrian sedimentary troughs and initial rift zones, become apparent for the Gondwana margin. The continuation of rifting, initially in a back-arc situation, triggered upwelling of asthenosphere, with contemporaneous Cambrian gabbros, granitoids and metamorphic conditions of lower crust (Abati et al. 1999) which announce the future opening of Rheic ocean. Comparable observations come from the Gotthard (Biino 1994) and Silvretta areas (Schaltegger et al. 1997). Pieces of oceanic crust, such as the Chamrousse area (Western Alps) or the Vesser zone (Saxothuringian zone), could represent the eastern continuation of the Rheic ocean (or pieces of oceanic crust contemporaneous to the Rheic ocean), and corresponding highly transformed relics of the same could be hidden among the many pieces of "amphibolites" found in the polymetamorphic areas of the Variscan mountain chain, indicating the former suture of an eastern continuation of an early Rheic ocean. Also the eclogitized remnants of Early Palaeozoic oceanic crust (Pulo do Lobo, Cabo Ortegal; Ordoñez Casado 1998) have to be incorporated in the general pattern of the Rheic ocean. Interestingly, Kleinschrodt and Gayk (1999) underlined the striking parallels of structural evolution and exhumation ages of the eclogite complexes of the Münchberg Massif and from Cabo Ortegal, former protoliths of the Rheic ocean.

Also Ordovician events known from the Avalonian plate have their contemporaneous events in the adjacent microcontinental plates. During the Ordovician break-up of Avalonia (485 Ma, Van Staal et al. 1998; East Avalonia, 480-465 Ma, Prigmore et al. 1997), the birth of the Rheic ocean, contemporaneous rift-related magmatism is observed in NW Spain (Fig. 4; Santos Zalduegui et al. 1995; Ordoñez Casado 1998; Fernandez-Suarez et al. 1999; Montero et al. 2000; ValverdeVaquero and Dunning 2000), in the French Central Massif (Pin and Marini 1993) and in the subterranes of the Saxothuringian domain (Linnemann et al. 1998a). Additional criteria for appreciating the general plate-tectonic situation are furnished by the widespread granitoid rocks of Early Palaeozoic age, by the evidence of an Ordovician orogenic event, and by the discussion of the possible continuation of Avalonian pieces preserved as relics in the former eastern continuation of Avalonia.

\section{Parallels of granitoid evolution}

During the plate-tectonic evolution of Avalonia (e.g. rifting related to the opening of Iapetus), accompanied by several magmatic cycles (e.g. early Cadomian, 580-570 Ma; Neoproterozoic, 550-540 Ma; CambroOrdovician, 500-480 Ma), and its break-off from Gondwana (formation of Rheic ocean, Cambro-Ordovician, 500-480 Ma), contemporaneous tectonic events and corresponding pulses of granitoids or their surface equivalents can be observed (Fig. 3) in most of the adjacent peri-Gondwanan continental blocks. Most Ordovician granitoids and acidic volcanic rocks from the Alps and areas outside the Alps (Fig. 4, 5), Avalonian outcrop areas (Tremblay et al. 1994; Keppie et al. 1997), the Himalayan domain (Girard and Bussy 1999), the Argentine Precordillera (Huff et al. 1998), and even from many Late Cadomian granitoids, independent of locality and age, show strong anomalies of $\mathrm{Ba}, \mathrm{Nb}, \mathrm{Sr}$ and $\mathrm{Ti}$ in mantle-normalized multi-element variation diagrams (von Raumer et al. 1999), and Late Proterozoic to Early Palaeozoic detrital sediments (e.g. Bollin 1994; Mingram 1996; Ugidos et al. 1997) 
Fig. 4 Ages of CambroOrdovician granitoids and metamorphism

Helvetic Realm

\author{
Alps \\ $438 \pm 5 \mathrm{Ma} \mathrm{U} / \mathrm{Pb}$ SHRIMP \\ $489 \pm 22 \mathrm{Ma}$ U/Pb Zrn \\ $496 \pm 6 \mathrm{Ma} \mathrm{U} / \mathrm{Pb} \mathrm{Zrn}$ \\ $453 \pm 3 \mathrm{Ma} \mathrm{U} / \mathrm{Pb} \mathrm{Zrn}$ \\ $436 \pm 17 \mathrm{Ma} \mathrm{Rb} / \mathrm{Sr}$ wr \\ $>440 \mathrm{Ma} \mathrm{U} / \mathrm{Pb} \mathrm{Zrn}$ \\ $439 \pm 5 \mathrm{Ma} \mathrm{U} / \mathrm{Pb} \mathrm{Zrn}$ \\ $445 \pm 2 \mathrm{Ma} \mathrm{U} / \mathrm{Pb} \mathrm{Zrn}$ \\ $456 \pm 2 \mathrm{Ma} \mathrm{U} / \mathrm{Pb} \mathrm{Zrn}$ \\ $\pm 450 \mathrm{U} / \mathrm{Pb} \mathrm{Zrn}$ \\ $461 \mathrm{Ma} \mathrm{Sm} / \mathrm{Nd}$ grt wr \\ $468 \mathrm{Ma} \mathrm{U} / \mathrm{Pb} \mathrm{Zrn}$ \\ 467-475 Ma U/Pb Zrn \\ $479 \pm 3 \mathrm{Ma} \mathrm{U} / \mathrm{Pb} \mathrm{Zrn}$ \\ 475-450 Ma U/Pb Zrn \\ $424 \mathrm{Ma} \mathrm{U} / \mathrm{Pb} \mathrm{Zrn}$
}

Penninic Realm

meta-dacite, Arg.

granite, Bell.

plagiogranite, Bell.

granitoids, Mt. Blanc

granitoids, Gotthard

migmatites, Aar massif

granitic gneiss, Si.

eclogite, Gotthard

eclogite, Gotthard

island arc gabbro, Gotthard

+ eclogite facies

island arc gabbro

metabasic protoliths

eclogite, Argentera

granophyre

Vanoise nord, granite

Peclet granite

Modane granite

metarhyolite, Ambin

alkaline granite

Vanoise,granite

granitic gneiss, Berisal

anatexis, Tauern

Austroalpine Realm

$450 \mathrm{U} / \mathrm{Pb} \mathrm{Zr}$

$458 \pm 11$ U-Pb SHRIMP

420-450 U/Pb Zrn

$451 \pm 2 \mathrm{Rb} / \mathrm{Sr}$ WR

$490 \pm 9 \mathrm{U} / \mathrm{Pb}$ EvZrn

$445 \pm 24 \mathrm{Rb} / \mathrm{Sr}$ WR

$494 \pm 73 \mathrm{Sm}-\mathrm{Nd}$ WR

$487 \pm 5 \mathrm{Sm}-\mathrm{NdT}$ it WR

$485 \mathrm{~Pb}-\mathrm{Pb}$ EvZrn

$468 \mathrm{Ma}$ U/Pb Zrn

$476 \pm 14 \mathrm{Ma} U / \mathrm{Pb}$ SHRIMP

Southalpine Realm

$466 \pm 5 \mathrm{Rb} / \mathrm{Sr}$ WR

$457 \pm 7 \mathrm{U} / \mathrm{Pb} \mathrm{Zrn}$

457-450 U/Pb, Pb/Pb

Ordovcian, stratigraphy

Saxothuringikum

$479 \pm 2 \mathrm{Ma}$ ev Zrn

$487 \pm 6$ Ma ev Zrn

$484 \pm 5 \mathrm{Ma}$ ev $Z \mathrm{rn}$

$485 \pm 6 \mathrm{Ma}$ ev Zrn

$486+4 \mathrm{Ma}$ ev Zrn

$\approx 490 \mathrm{Ma}$ ev Zrn

Bohemian Massif + Schwarzwald

$\pm 480$

$487 \pm .8 \mathrm{Ma} \mathrm{U} / \mathrm{Pb}$ SHRIMP

$482 \pm 6$ SHRIMP Zrn

$\approx 480 \mathrm{Ma} \mathrm{Rb} / \mathrm{Sr}$ recalc

501-504 Ma U/Pb EvZrn

$469.3 \pm 3.8 \mathrm{Ma}$ SHRIMP Zrn

$481.7 \pm 1.1 \mathrm{Ma} \mathrm{Pb} / \mathrm{PbEv} \mathrm{Zrn}$

$485 \pm 12 \mathrm{Ma} \mathrm{Pb} / \mathrm{Pb}$ EvZrn

$480 \pm 12 \mathrm{Ma} \mathrm{Pb} / \mathrm{Pb}$ EvZrn

Polish Sudetes

480-505 U/Pb Zrn

473-488 U/Pb EvZrn

440 U/Pb EvZrn

NWlberia +Ossa Morena

$500 \pm 2 \mathrm{U} / \mathrm{Pb} \mathrm{Zrn}$
$484,493 \mathrm{U} / \mathrm{Pb} \mathrm{Zrn}$
$465-480 \mathrm{U} / \mathrm{Pb} \mathrm{Zrn}$
$479.5 \mathrm{Ma} \mathrm{U} / \mathrm{Pb} \mathrm{Zrn}$
$480 \pm 2 \mathrm{Ma} \mathrm{U} / \mathrm{Pb} \mathrm{Zrn}$
$502 \pm 8 \mathrm{MaPb} / \mathrm{Pb} \mathrm{Zrn}$
$480 \pm 7 \mathrm{Ma} \mathrm{Pb} / \mathrm{Pb} \mathrm{Zrn}$
French Massif Central
$478 \pm 6 \mathrm{Ma} \mathrm{U} / \mathrm{Pb} \mathrm{Zrn}$
Hungary
$462 \pm 6 \mathrm{~Pb} / \mathrm{Pb}$ Ev Zrn
Turkey

Ord, age, fossils
Flüela-granite, Silv

Flüela-granite, Silv

Ötztał, migmatite

gramitoid gneiss, TS.

Otztal meta-granite

Ötztal meta-granite

Ötztal meta-granite

Porphyroid Greywacke zone

Metagabbro Greywacke zone

Ceneri gneiss

Staur. formation

Comelico-Porphyroid

Bärentiegel Porphyroid

Blambach Rhyolite

rhyolitic tuff Wurzelberg

Tourmaline granite

Metarhyolite

rhyolite pebbles

ZEV, pegmatoids, metamorphism

Metaeklogite

Gföhl gneiss

thermic event

granitoids

inherited magm. Grains

Frankenstein gneiss

Metarhyolith Ehrenfriedersdorf

Augengneiss Schwarzenberg

granitoids

Gory Sowie

anatectic granitoid

orthogneiss

migmatization

Olso de Sapo granitoid

meta-granodiorite

Cardoso gneiss

Castillo alkaline granite

Valuengo microgranite

orthogneiss, "leptynite"

granitic gneiss, Sakarya

granite pebbles, Tisia
Lombardo et al. 1997

Barféty et al. 1997

Ménot et al. 1988 .

Bussy \& von Raumer 1994 Arnold 1970

Bossart et al. 1986

Sergeev \& Steiger 1993

Schaltegger 1993

Köppel et al. 1981

Gebauer et al. 1988:

Oberli et al. 1994:

Abrecht et al. 1995:

Paquette et al. 1989:

Paquette et al. 1989:

Guillot et al. 1991

Guillot et al. 1998

Guillot et al. 1998

Guillot et al. 1998

Guillot et al. 1998

Bussy et al. 1996

Bertrand \& Leterrier 1997

Köppel et al. 1981

Eichhorn et al, 1999

Liebetrau 1996

Flisch 1987

Klötzli-Chovanetz et al. 1997

Hammerschmidt 1981

Hoinkes et al. 1997

Bernhard et al. 1996

Bernhard et al. 1996

Söliner et a!. 1991

Loth et al. 1999

Boriani et al. 1981

Zurbriggen et al. 1997

Romer et al. 1996

Romer \& Franz 1998

Hubich \& Loeschke 1993

Linnemann et al. 2000

Linnemann et al. 2000

Linnemann et al. 2000

Linnemann et al. 2000

Linnemann et al. 2000

Linnemann et al. 2000

O'Brien et al. 1997

'Brien and Kröner 1999

Friedl et al. 1998

Chen et al. 2000

Kröneret al. 2000

Kröner et al. 2000

Kröner and Willner 1998

Mingram \& Rötzler 1999

Mingram \& Rötzler 1999

Oliver et al. 1993

Kröner \& Hegner 1998

Abati et al. 1999

Gonzalez Cuadra et al. 1999

Fernandez-Suarez et al. 1999

Santos Zalduegui et al. 1995

Valverde-Vaquero \& Dunning 2000

Montero et al. 2000

Montero et al. 2000

Pin and Lancelot 1982

Özmen and Reischmann 1999

Kozur 1984 a,b 


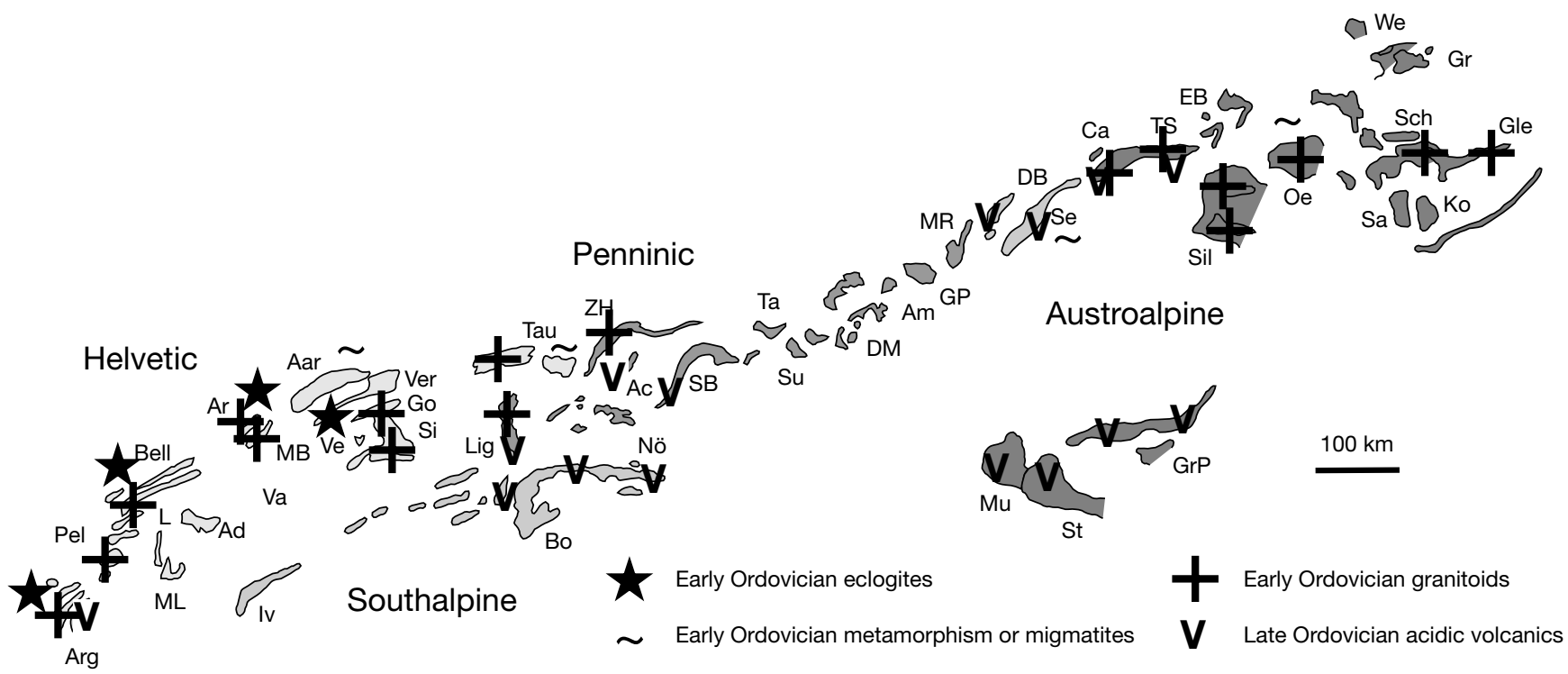

Fig. 5 Distribution of Ordovician granitoids in the Alpine domain - a tentative Silurian projection. Granitoids represent different stages of evolution of polymetamorphic domains at an active margin, and in relation with an Ordovician amalgamation, whereas late Ordovician volcanites represent the nearby situation of the opening Palaeotethys. Helvetic domain: Aar Aar massif; Ad Adula; AR Aiguilles Rouges massif; Arg different pieces of the Argentera massif, Bell Belledonne-Grandes Rousses; Go Gotthard massif; $L$ Lebendun; $M B$ Mont-Blanc; $M L$ Monte Leone; Si Simano; Tau Tauern window units; Ve Verampio basement; Ver Carboniferous in the Verrucano unit. Penninic units: Ac Acceglio unit; Lig different pieces in the Ligurian Alps (new Ordovician age data, oral comm. M. Molina, Genova); $S B$ St. Bernhard nappe; $S u$ Suretta; Ta Tambo; $V a$ Vanoise unit; $Z H$ Zone Houillère. Austroalpine units: $A m$ Ambin; $C a$ Campo; $G l$ Gleinalm; $D M$ different pieces in the Dora Maira unit; EB Err-Bernina units; Gle Gleinalm; GP Gran Paradiso; $G r$ Grobgneis unit; GrP Graz Palaeozoic; Iv IvreaZone; Ko Koriden; MR Monte Rosa; Mu Murau nappe; Oe Oetztal; Sa Saualm; Sil Silvretta nappe; St Stangalm; Sch Schladminger Tauern; Ve Veitsch units; We Wechsel unit. Southalpine units: Bo Bozen; $D B$ Dt. Blanche; Iv Ivrea zone; Nö Nötsch; $K W$ Karawanken; $K a$ Karnische Alpen; Se Sesia-zone

show similar normalized patterns indicating chemical homogeneity over wide areas. Such large-scale parallels, which may have resulted from comparable source areas of granitoids or sediments, show that normalized multi-element variation diagrams do not discriminate the plate-tectonic situation of the many granitoids.

Comparing trace elements, Linnemann et al. (2000) show that Cadomian detrital sediments of the Saxothuringian zone indicate the situation of a continental island arc, whereas Ordovician sediments carry the fingerprints of a passive margin. In geochemical plots (Maniar and Piccoli 1989), the Cambro-Ordovician granitoids follow, in some ways, distinct steps of a plate-tectonic evolution (Fig. 6). Local occurrences of Cambrian plagiogranites (Alps: Ménot et al. 1988, Müller et al. 1996; NW Iberia, Espasante) document evolution of oceanic crust, and Cambrian granitoids of more alkaline and metaluminous compositions (Alps:
Guillot et al. 1991, Bussy et al. 1996; Ossa Morena: Montero et al. 2000; Pyrenees: Navidad and Carreras 1995) may have formed in a thickened crust (see also NW Iberia; Santos Zalduegui et al. 1995). Equally, in the Cambro-Ordovician granitoid associations (e.g. Oetztal, Schindlmayr 1999; Silvretta, Liebetrau 1996; External massifs, Wirsing 1997), the relatively early calc-alkaline metaluminous trends can be related to a Cambro-Ordovician active margin setting (Schaltegger et al. 1997; Schermaier et al. 1998), whereas the corresponding relatively younger granitoids $( \pm 450 \mathrm{Ma})$ have more or less calc-alkaline peraluminous compositions, carrying the characteristics of a late- to postorogenic evolution. When plotted on a $\mathrm{Rb} / \mathrm{Y}+\mathrm{Nb}$ diagram (Pearce et al. 1984), older granitoids of Ordovician age in the Alps plot in the fields of VAG or intra-plate situation.

\section{Post-Cambrian evolution of microcontinents}

The presence of Cambro-Ordovician active margin setting, Ordovician rifting and the evolution of Cambro-Ordovician granitoids raises the question of the existence of an orogenic event characterizing part of the Gondwana margin. The presence of so many Ordovician granites and their pre-Variscan organization (Fig. 5) and geochemical evolution leads, necessarily, to the question of their plate-tectonic situation (Schmidt 1977; Ebner et al. 1987; Biino 1995; Oberli et al. 1994; Abrecht et al. 1995; Handy et al. 1999; O'Brien et al. 1997). Ordovician ages of granitoids (Fig. 4, with references), of eclogites (Nussbaum et al. 1998, not precise age; Gebauer et al. 1988; O'Brien and Kröner 1999) as well as anatexis and metamorphism (Schaltegger 1992, 1993; Klötzli-Chovanetz et al. 1997; Ordovician subduction, Biino 1994; O'Brien et al. 1997; Zurbriggen et al. 1997; Weger et al. 1999; staurolite formation, Romer and Franz 1998) 


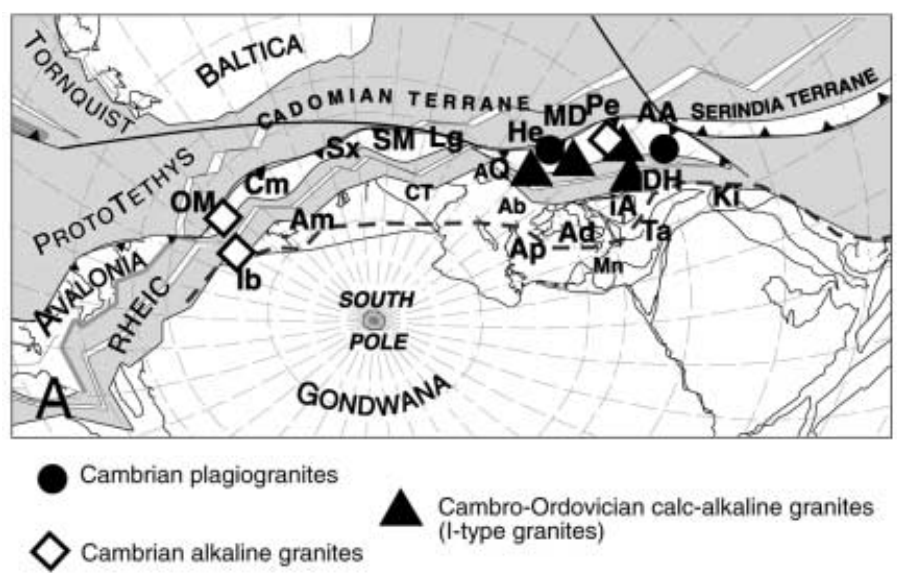

Fig. 6A, B Distribution of Early Palaeozoic granitoids at the peri-Gondwanan margin (nomenclature and reconstructions: see Fig. 7). A Early Ordovician reconstruction (Fig. 7A) with location of granitroids emplaced before the opening of the Rheic ocean. B A Silurian projection Fig. 7B) with granitoids and metamorphism related to the Ordovician orogenic event and to the opening of Palaeotethys

argue for the orogenic evolution from an active margin setting to a collision during a short time period (e.g. Gotthard massif, 5-20 Ma, Oberli et al. 1994: 467- to 475-Ma intrusion of metagabbros/440-Ma metamorphism of Streifengneis granitoids). Carmignani et al. (1994) discuss an evolution from Cambrian rift to an Ordovician Andean type margin for Sardinia. The coincidental evolution of certain types of granitoids through time mentioned previously confirms a platetectonic evolution including collisional and post-collisional events. We interpret the tectonic assemblage of Cadomian relics, Neoproterozoic arc setting, and/or Late Proterozoic to Early Palaeozoic sediments and oceanic crust, and Ordovician orogenic structures as indicating an Ordovician suture zone, where these elements were amalgamated to Gondwana during the Ordovician (Figs. 7, 8).

Ordovician palaeo-oceanographic reconstructions combine palaeocurrent data (Christiansen and Stouge 1999), palaeomagnetic criteria (MacNiocaill et al. 1997; Torsvik and Smethurst 1996) and faunal distributions (Harper et al. 1996; Paris 1993; Paris et al. 1999; Mélou et al. 1999) defining the Iapetus and Rheic oceans domains. The wide domain of Iapetus is characterized, since the Early Ordovician, by faunal provinces of brachiopods, where the peri-Gondwanan Avalonian border has cold-water Celtic faunas (Harper et al. 1996; Cocks 2000), and volcanic arc activity (MacNiocaill et al. 1997). Characteristics of Chitinozoan faunas give an idea about the early evolution of the Rheic ocean (Paris 1993; Paris et al. 1999) and, during the same time period, detrital sediments record maximum of subsidence and rift basin formation, accompanied by rift volcanism, in lateral continuity (e.g. Saxothuringian domain; Linnemann 1999).

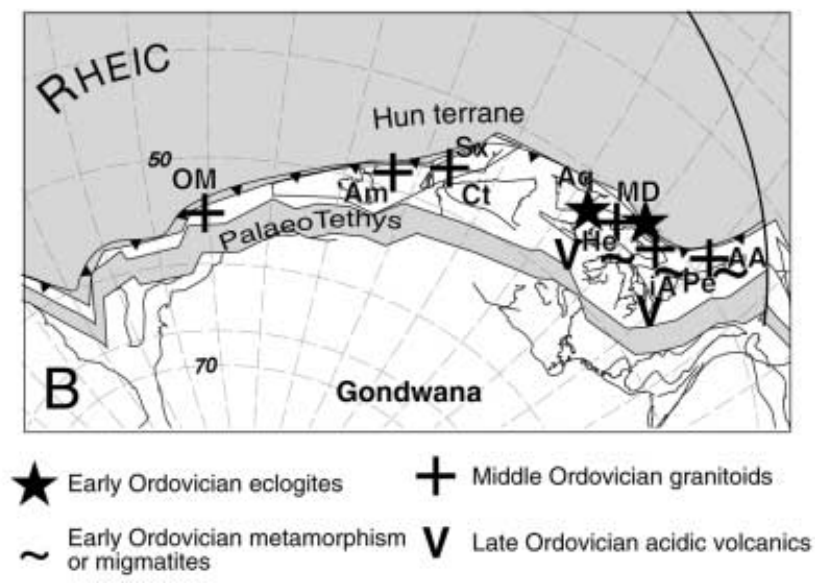

Sedimentary basins, constituting the lower Palaeozoic cover series in the Eastern Alps, contain acidic volcanics among lower Palaeozoic sediments (Loeschke and Heinisch 1993) with a well-documented sedimentary evolution (Schönlaub 1997a, 1997b; Schönlaub and Heinisch 1993; Schönlaub and Histon 2000), representing a rifting environment since the Late Ordovician (Neubauer and von Raumer 1993; Neubauer and Sassi 1993; Sassi et al. 1994). Since the Late Ordovician, many areas are covered by the detrital sediments of Ordovician glaciation (e.g. Hamoumi 1999; Linnemann et al. 1999). It is only after the onset of the Avalonian drift that Armorica and the more easterly situated Intra-Alpine blocks followed a more independent plate-tectonic evolution.

\section{Terrane detachment from Gondwana}

Detachment from Gondwana started during the MidOrdovician (ATA; Tait et al. 1998), Caradoc/Ashgill (Saxothuringian domain, $445 \mathrm{Ma}$; Fig. 3; Linnemann et al. 1998b), and the latest Ordovician (Alpine domain, Ashgill/Llandovery, 435 Ma; Fig. 3; Stampfli 1996) when the Palaeo-Tethys rift opened. Sedimentological and faunistic criteria, and palaeomagnetic data, gave rise for models of detachment of Gondwana-derived continental blocks during the Ordovician and Silurian, favouring either the separation of a basement assemblage (Stampfli 1996) or a major mid-European oceanic separation (Robardet et al. 1990).

Stampfli (1996) introduced the Hun-Terrane model, a ribbon-like assemblage of continental blocks, not necessarily above sea level, or volcanic islands, including Armorica, the Intra-Alpine basement and microcontinents situated in the eastern prolongation. The observation of subsidence patterns in former periGondwanan domains induced Stampfli (2000), and Stampfli and Mosar (1996), to reconstruct the contours of Palaeo-Tethys during the Early Silurian for the Intra-Alpine domains and the corresponding eastern prolongations. Prior to their Silurian separation from Gondwana, these Variscan terranes were located 
Fig. 7 A Location of pre-Variscan basement units at the Gondwanan margin during the Early Ordovician (490 Ma), modified from Stampfli (2000), showing the early stages of the Rheic ocean spreading. B A Silurian projection (420 Ma), modified from Stampfli (2000), showing the early stages of opening of PalaeoTethys. Baltica: Is Istanbul; Mo Moesia; $Z g$ Zonguldak. Avalonia: $M M$ Meseta-Meguma. Cadomia: $A A$ Austro-Alpine; $\mathrm{Cm}$ Cadomia s.str.; $\mathrm{He}$ Helvetic; $L g$ Ligerian; $M D$ Moldanubian; $O M$ Ossa-Morena; Pe Penninic; $S M$ Serbo-Macedonian; $S x$ Saxothuringian. Serindia: $K T$ Karakum-Turan; Tn north Tarim. Gondwana: $A b$ Alboran; Ad Adria; Al Alborz; $A m$ Armorica; $A p$ Apulia; $A q$ Aquitaine; $C t$ Cantabria; $D H$ Dinarides-Hellenides; $i A$ intraAlpine; $I b$ Iberia; $K i$ Kirshehir; $L T$ Lut-Tabas; $M n$ Menderes; Pr Pamir; SS

Sanadaj-Sirjan; $T a$ Taurus; $T s$ south-Tarim

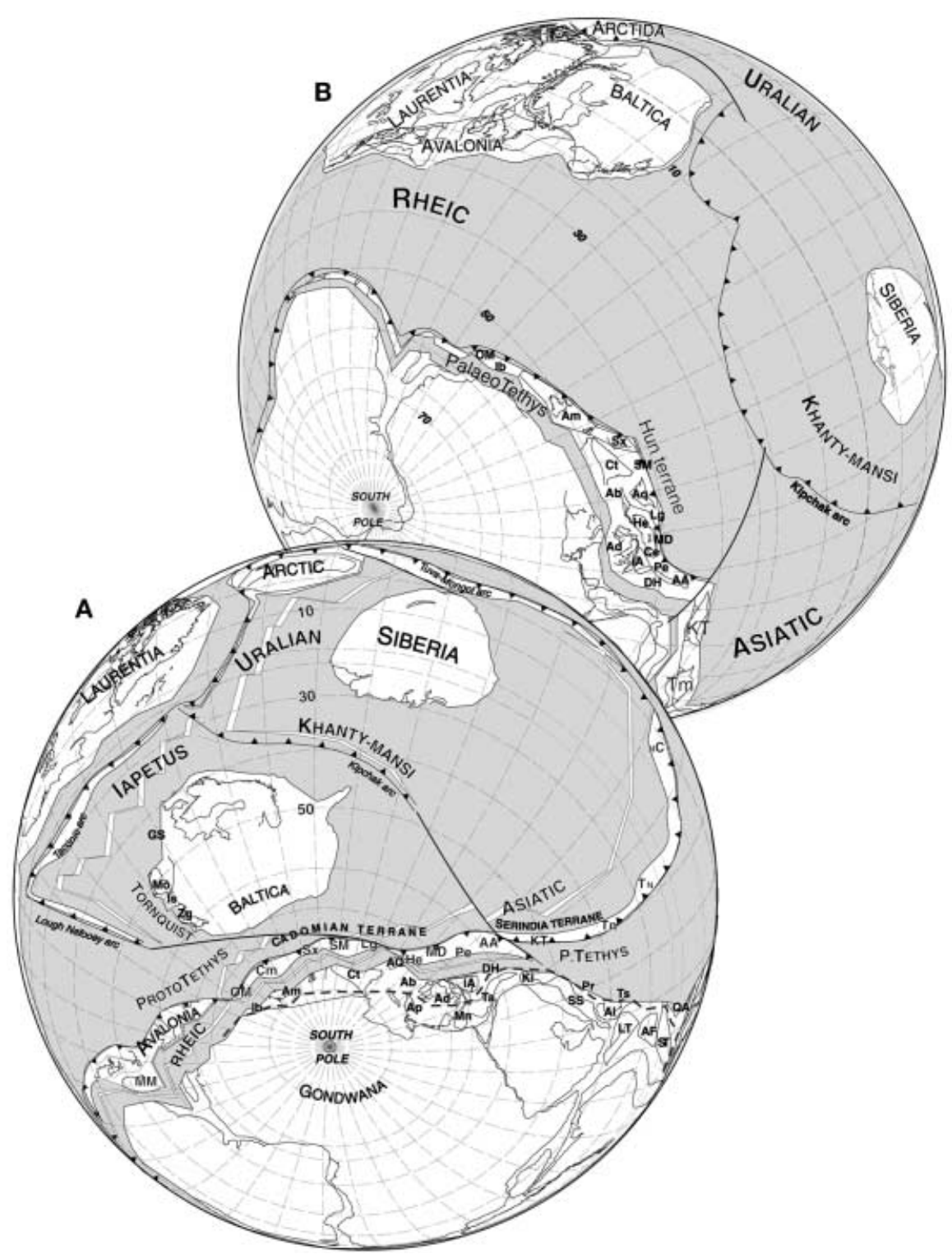

along the margin of Gondwana and represent the future northern margin of Palaeo-Tethys. Consequently, a tentative Silurian palaeo-tectonic configuration has been derived by back-modelling the present day distribution of Variscan elements in Europe (Fig. 7), including also the basement areas of Armorica assumed to contain relics of a former rifting period since the Ordovician.

The corresponding palaeo-reconstuctions are based on palaeomagnetic pole data and have been developed with the GMAP software package (Torsvik and Smethurst 1994; Torsvik and Smethurst 1999) using an orthographic (orthogonal) projection. The Early Ordovician (490 Ma) projection is centred on present-day latitude $60^{\circ} \mathrm{N}$, longitude $80^{\circ} \mathrm{E}$, the Late Silurian (420 Ma) projection is centered on present-day latitude $10^{\circ} \mathrm{N}$, longitude $25^{\circ} \mathrm{E}$. The palaeomagnetic pole data used for Baltica are from Torsvik et al. (1994) for the Hun terranes elements and Siberia from Van der Voo (1993), and references therein. The position of Gondwana is constrainded by the Australia data from Klootwijk (1996) and by Pangea tight-fit reconstruction. The Baltica poles are the absolute reference poles for all the reconstructions.

As a result of Ordovician to Early Devonian rifting events, the components of the Hun terrane were stepwise detached from Gondwana accompanying the opening of Palaeo-Tethys. Such reconstructions are not too different from palaeomagnetic reconstructions for the Armorican Terrane Assemblage (ATA; Tait et al. 1998), where distinct groups of microcontinents started to separate from Gondwana. The principle of a Hun-Terrane, which is grouping of certain microcontinental pieces, may thus be modified acknowledging a still more detailed individual separation from Gondwana. If we admit an opening of Palaeo-Tethys in a 
Fig. 8 Cross sections model to illustrate the possible plate tectonic evolution between Baltica and Gondwana during the Early Palaeozoic. The Hun-superterrane resulted from the Ordovician collisional assemblage of elements possibly detached from Baltica-Siberia and areas comprising Cadomian basement (former eastern prolongation of Avalonia), Early Palaeozoic oceanic crust (Rheic), volcanic arcs and accretionary wedges, with the Gondwana margin. The opening of the Palaeotethys separated the composite Hun superterrane from Gondwana. This opening took place in a context of back-arc spreading of Palaeotethys and slab roll-back of the Mauretanian-Rheic ocean and was accompanied by the formation of volcanics

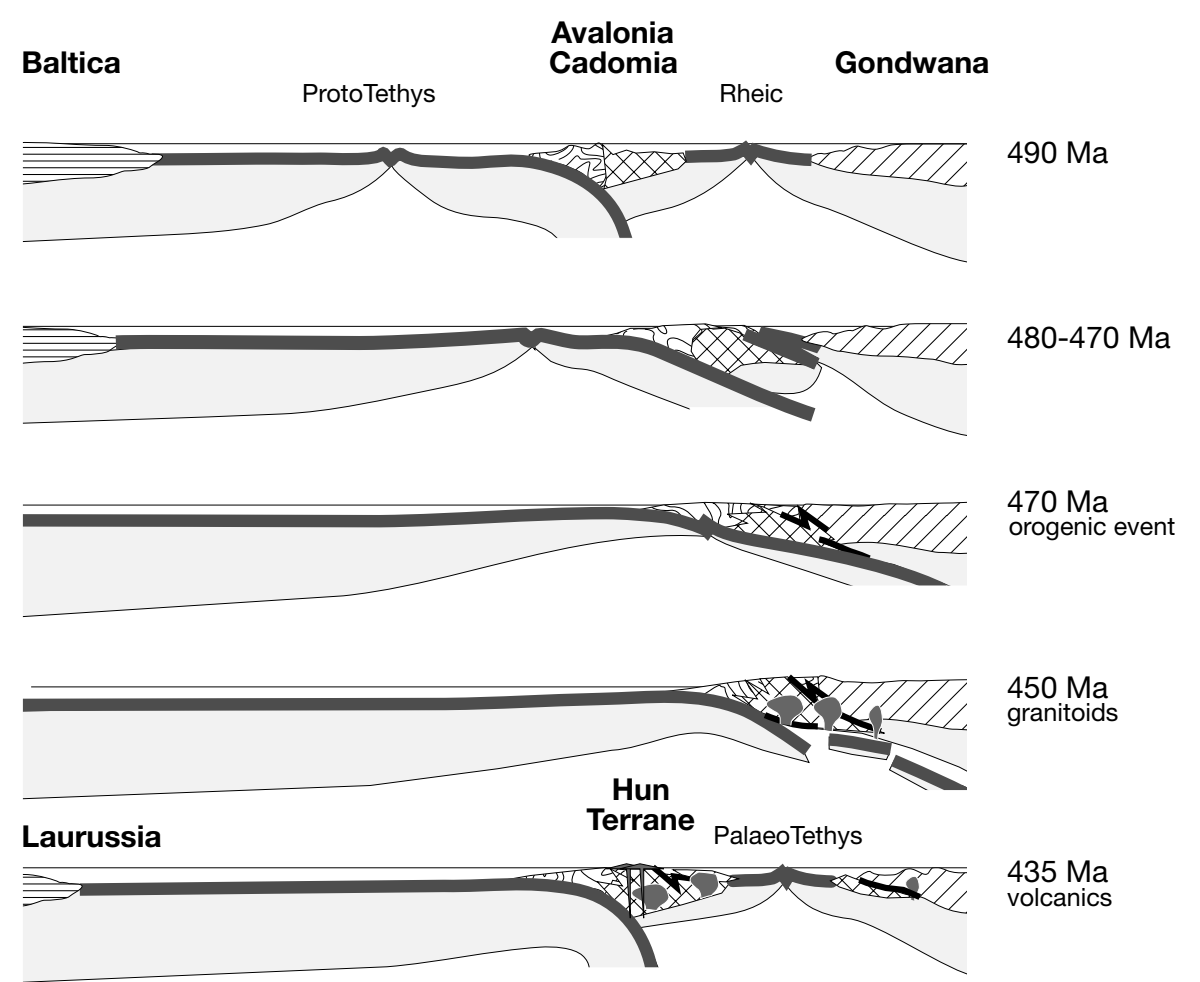

back-arc setting, the geometry of the detached upper plate is bound to be modified by differential slab rollback behaviour of the lower plate as is observed presently along the Mariana trench, for example. It is clear that the opening of Palaeo-Tethys is diachronous (Stampfli 2000); however, subsidence curves alone cannot determine the onset of sea-floor spreading when very little Palaeotethyan sea-floor remnants are known. We propose a detachment of Gondwanan elements in three major steps: firstly, the Avalonia blocks; then, the mainly European Hun Terranes; and finally the Far-East Hun terranes. We assume that the latter could not be detached before the Silurian accretion to Gondwana of some exotic (Baltica-Siberia) elements grouped here as Serindia. There, the situation is quite different, amalgamation of terranes happened only in Silurian or Early Devonian times and larger continental fragments are involved such as the Pamir-south Tarim-Tsaidam block collision with the north Tarim-north China block (Yin and Nie 1996) or the north Qinling north China blocks collision (Meng and Zhang 1999). These drifting exotic blocks (Serindia terrane) followed the slab roll-back of the ProtoTethys accompanied by the Asiatic ocean spreading in a back-arc position. An older western portion of the Asiatic ocean was involved in intra-oceanic subduction accompanied by the opening of the Khanti-Mansi back-arc ocean and development of the Kipchak arc (Sengör and Natal'in 1996). A southward connection between the Asiatic ocean mid-oceanic ridge and a remnant Proto-Tethys mid-oceanic ridge is suggested here. This Silurian collisional event affected also the
South China block and part of the Indochina block (or the north Qinling north China blocks collision; Meng and Zhang 1999; Findlay 1997) and possibly has been recognized westward up to eastern Turkey (Göncüoglu and Kozur 1999).

\section{Scenario of peri-Gondwanan evolution: a conclusion}

When summing up the observations mentioned previously, we arrive, independently of Variscan tectonic complications, at the conclusion that most of pre-Variscan relics of the Variscan mountain chain had their origin at the Gondwana margin. Two evolution trends are noted:

1. Stampfli (2000) favoured the derivation of Cadomian basement blocks from Baltica triggered by a Baltica-directed subduction and island arc formation during the Early Ordovician which, during the Mid Ordovician, collided with the Gondwana margin (orogenic event). Inversion of subduction towards Gondwana produced the break-off of the Hun-superterrane and formation of Palaeo-Tethys as a back-arc ocean.

2. In our present model an opposite evolution is proposed for the Cadomian terrane. Assuming that already since the latest Precambrian subduction was generally directed towards Gondwana (Cadomian orogeny, Avalonian southern prong), we assume that most of the Cadomian basement blocks (exception Belka et al. 1998, 1999; Unrug et al. 1999) presently hidden in the Variscan mountain 
chain should have derived from the Gondwana margin ("European margin"; Courjault-Radé et al. 1992). In this general picture, the Serindia terrane is still considered as derived from Baltica-Siberia.

Since the latest Cambrian (500 Ma) at several locations (see above) magmatic and metamorphic events are dated, presumably the consequence of general crustal extension and contemporaneous influence of rising asthenosphere. Such activity is accompanied, at several distant places, by formation of oceanic crust interpreted to represent the opening of the Rheic ocean. The alignment of the very different localities at the Gondwana margin suggests a contemporaneous opening over a large distance, from Ossa Morena, and Iberia to the Münchberg Massif. The question arises as to whether such oceanic trenches represent one uninterrupted long suture line, or if there existed parallel lines of opening (e.g. Rheic, Galicia-Massif Central; Matte 1986), compared with the parallel lines of Early Cambrian grabens intersecting the Gondwanan block. The large differences of oceanic crust at the different localities may indicate that oceanic crust did not result from cylindrical subduction and simultaneous slab roll-back, but from very oblique convergence, where either pull-aparts may have facilitated the appearance of true oceanic crust, accompanied laterally by only incomplete oceanic series, or simply volcanites and/or detrital sediments. Such strike-slip models have been proposed by Murphy and Nance (1989), Linnemann et al. (1998b) and Zulauf et al. (1999).

The striking parallels of evolution from the Late Neoproterozoic to the earliest Ordovician are best explained when using a ribbon-like lining-up model of pre-Variscan blocks along the Gondwana margin. Most of the continental pieces contain the relics of a Neoproterozoic active-margin setting and continental rift since the Late Cadomian, and early stages of Rheic ocean. Intrusion of granitoids and volcanites follow the regional tectonic pattern. We thus claim a common early evolution of Avalonia and its eastern continuation (e.g. Cadomia sensu lato, Intra-Alpine Terrane) at the Gondwana margin, and major differences of evolution between Avalonia and the remaining eastern microcontinents only after the successful break-off of Avalonia during the Early Ordovician (Figs. 3, 7, 8).

The independent drift story of the microcontinents situated in the eastern prolongation of Avalonia depended on the time of subduction of a remnant Proto-Tethys/Rheic mid-oceanic ridge; the latter was linked with the Asiatic ocean mid-oceanic and transform zone in between. The subsequent subduction/collision of the ridge/transform zone triggered the amalgamation of arc and continental ribbon with Gondwana leading to the Ordovician orogenic evolution. This collisional event produced a complex terrane configuration, the "Noric composite Terrane" (Eastern Alps; Frisch and Neubauer 1989) or "Hun superterrane" (Stampfli 1996). It comprises older (former Gondwanan) basement blocks, accretionary wedges, volcanic arcs, and pieces of an aborted eastern Rheic ocean, and may have, locally, the aspect of an archipelago, but it also can be composed by large continental blocks. It is evident that there has been tectonic interaction between the different elements, thus complicating the orogenic assemblage, and our proposed distribution of terranes (Fig. 7) is only tentative. As traces of the Ordovician orogenic event are seen mainly in the Intra-Alpine domain, with some parallels in the Bohemian massif (Cambrian and Ordovician zircon ages of eclogites; O'Brien and Kröner 1999), the question arises as to whether the Armorican Terrane Assemblage (Tait et al. 1998) and more western situated microcontinents were really independent from the more eastern ones, and that the assemblage of Bohemian massif and the Intra-Alpine terranes had a distinct drift history, interrupted by this short event, or if the Devonian lower crustal events observed in the more western parts have completely erased the memory of such events. The evidence of Early Ordovician volcanites and/or granites, sometimes of alkaline tendencies, in the more western blocks just indicates the rifting related to the break-off of Avalonia.

The constituents of the future Hun-composite terrane are interpreted to represent an eastern prolongation of Avalonia (Figs. 3, 7), and the suture zone hidden in the superterrane are interpreted to represent the eastern prolongation of an early stage of the Rheic ocean (see also Finger et al. 1998), before the Ordovician amalgamation (Figs. 7, 8). This amalgamation would have been the result of a diachronous consumption of the mid-ocean ridge of Proto-Tethys which triggered the intrusion of late Cadomian granitoids and consequently the early separation (480 Ma) of Avalonia from its neighbouring blocks following the onset of generalized slab roll-back of the remaining ocean. The opening of the eastern branch of the Rheic was stopped by the contemporaneous spreading of the Asiatic ocean (Zonenshain et al. 1985) and partial collision with a major transformation zone at the southern end of the exotic Karakum-Tarim-north China terrane. It is only since the break-off of Avalonia that the plate-tectonic evolution of the more eastern-situated microcontinents (e.g. Cadomia, Intra Alpine Terrane) became different, and the following events could have been the consequence of accretion and shifting of subduction zones to external domains, as discussed for the contemporaneous evolution at the Pacific Gondwana margin (Rapela et al. 1992; Tessensohn 1999).

The time period after the Ordovician amalgamation is characterized by the sucessive stages of subduction, and the contemporaneous formation of accretionary wedges and arc-volcanics at the Silurian active margin of Gondwana. This is supported by Silurian eclogite ages from the Tauern area (von Quadt et al. 1997) and comparable ages from the Argentera External 
Massif (Paquette et al. 1989), and the Massif Central domain (e.g. Ducrot et al. 1983; high-pressure event: Pin and Lancelot 1982). Relics of Silurian volcanic arcs have been recognized in the domain of the North German Crystalline Rise, interpreted as an active margin setting in the South of the Rhenohercynian domain (Altenberger and Besch 1993; Reischmann and Anthes 1996a, 1996b; Zeh et al. 1997), and in our model the active margin is located on the northern border of the Hun-superterrane (Figs. 7, 8). The diachronous Palaeo-Tethys opening in Silurian-Early Devonian times is viewed as a back-arc opening along the Gondwana margin (Stampfli et al. 1991; Stampfli 2000). Faunistic assemblages (Schönlaub 1997a, 1997b; Schönlaub 1993; Schönlaub and Histon 2000) and palaeomagnetic data (Bachtadse et al. 1995; Schätz et al. 1997; Tait et al. 1998; Torsvik et al. 1994; Torsvik and Eide 1998) support the migration of the Hun superterrane towards Laurussia. It is interesting that Noblet and Lefort (1990) admit in their lower Ordovician stratigraphy a "future opening of the Tethys I ocean", and that in the Silurian palaeogeographic reconstruction (Paris and Robardet (1990) admit an opening oceanic domain as a branch of the Rheic ocean for the more eastern-situated domains of the large Gondwana shelf.

Difficulties arise when comparing drift models of continental pieces since the Silurian. Matte (1986) and Robardet (1996) propose the migration of Gondwana towards Laurussia, whereas Tait et al. (1998), based on palaeomagnetic data, discuss the migration of individual microcontinents or groups of continents, coinciding with predictions based on faunistic criteria (Schönlaub 1993), and such models could be correlated with a modified model of the Hun-superterrane and its migration (forthcoming discussion given by G.M. Stampfli et al., submitted).

Considering the parallels of pre-Variscan evolution of the different microcontinents preserved in the Variscan domain (Fig. 3), it is tempting to propose a nomenclature for the classical tectono-stratigraphic realms, taking into account the former geological evolution at the Gondwana margin. The assemblage of Cadomian basement, Neoproterozoic to Cambrian active margin setting, and Ordovician accretionary stages represent the leading edge of the Hun-superterrane and includes a Middle Ordovician suture of aborted Rheic ocean. Large areas of the Moldanubian, of the French Central Massif and from NW Iberia can be grouped under this assemblage. The units, characterized by the opening of the Paleo-Tethys which separated the Hun super-terrane from Gondwana in Late Silurian times, belong to the classical Saxothuringian domain and the southern part of Armorica s.l. As a consequence of the Variscan evolution since the Silurian (G.M. Stampfli et al., submitted), the classical Rhenohercynian zone together with the Lizard domain, and the South Portuguese and Moravo-Silesian zones, opened as a Devonian oceanic domain within the Laurussia margin, due to Gondwana-directed slab pull. The contemporaneous leading edge of the Hun-superterrane is represented by the Silurian-Devonian active margin (part of the mid-German Crystalline Rise).

Although the proposed models do not contradict palaeoreconstructions in terms of palaeomagnetic information and faunal distributions mentioned previously, an interdisciplinary discussion is still needed to better understand plate-tectonic evolution during Early Paleozoic times. Important information on key areas are still lacking, and we view this paper as stimulation for further discussion and research, which has started already through the stimulating contribution from the reviewers. Little is known about the larger distribution of the Ordovician orogenic event, and precise age determinations of magmatic rocks or refined provenance studies of sedimentary rocks, even of high-grade metamorphic rocks, are greatly needed.

Acknowledgments We sincerely thank W. Franke (Giessen), D. Harper (Kopenhagen), E. Hegner (München), A. Kröner (Mainz), U. Linnemann (Dresden), M. Molina (Genova), D. Nance (Athens), F. Paris and M. Robardet (Rennes), P. Ryan (Galway), and Heinz Kozur for providing unpublished data or manuscripts or stimulating discussions. P. Matte (Montpellier), J. Mosar (Oslo), B. Murphy (Antigonish) and H.P. Schönlaub (Vienna) are thanked for their engaging reviews and the many suggestions which helped considerably to clear up differences of interpretations.

\section{References}

Abati J, Dunning GR, Arenas R, Diaz Garcia F, Gonzalez Cuadra P, Martinez Catalan JR, Adonaegui P (1999) Early Ordovician orogenic event in Galicia (NW Spain): evidence from $\mathrm{U}-\mathrm{Pb}$ ages in the uppermost unit of the Ordenes Complex. Earth Planet Sci Lett 165:213-228

Abrecht J, Biino G, Schaltegger U (1995) Building the european continent: late Proterozoic-Early Palaeozoic accretion in the Central Alps of Switzerland. Terra Nova 5 Abstr (Suppl I): 105

Altenberger U, Besch T (1993) The Böllstein Odenwald: evidence for pre- to Early Variscan plate convergence in the Central European Variscides. Geol Rundsch 82:475-488

Andonaegui P, Gonzalez del Tanago J, Arenas R, Abati J, Martinez Catalan JR, Peinado M, Diaz Garcia F (1999) Tectonic setting of the Monte Castelo gabbro (Ordenes Complex, NW Iberian Massif): evidence for an arc-related terrane in the hangingwall to the Variscan suture. EUG10 Annual meeting11:400

Arnold A (1970) On the history of the Gotthard Massif (Central Alps, Switzerland). Eclog Geol Helv 63:29-30

Bachtadse V, Torsvik TH, Tait JA, Soffel HC (1995) Paleomagnetic constraints on the paleogeographic evolutionof Europe during the Paleozoic. In: Dallmeyer RD, Franke W, Weber K (eds) Pre-Permian geology of central and eastern Europe. Springer, Berlin Heidelberg New York, pp 567-578

Bard JP (1997) Démembrement anté-mésozoïque de la chaîne varisque d'Europe occidentale et d'Afrique du Nord: rôle essentiel des grands décrochements transpressifs dextres accompagnant la rotation-translation horaire de l'Afrique durant le Stéphanien. C R Acad Sci Paris 324:693-704

Barféty JC, Gidom M, Ménot RP, Debon F, Pecher A, Guillot S, Fourneaux JC, Gamond JP (1997) Notice de la feuille Domène (773) 
Belka Z, Ahrendt H, Franke W, Schäfer J, Wemmer K (1998) Early Palaeozoic accretion of Gondwana-derived terranes at the margin of Baltica: evidence from $\mathrm{K} / \mathrm{Ar}$ ages of detrital muscovites and faunistic data. Acta Univ Carolinae. Geologica 42:211-212

Belka Z, Ahrendt H, Franke W, Schäfer J, Wemmer K (1999) Accretion history of the Trans-European suture zone viewed from new provenance and biogeography data. Terra Nostra 99:60-61

Bernhard F, Klötzli US, Thöni G, Hoinkes G (1996) Age, origin and geodynamic significance of a polymetamorphic felsic intrusion in the Ötztal crystalline basement. Mineral Petrol 58:171-196

Bertrand JM, Leterrier J (1997) Granitoïdes d'âge Paléozoïque inférieur dans le socle de Vanoise méridionale: géochronologie $\mathrm{U}-\mathrm{Pb}$ du métagranite de l'Arpont (Alpes de Savoie, France). CR Acad Sci Paris 325:839-844

Biino G (1994) The pre-Late Ordovician metamorphic evolution of the Gotthard-Tavetsch massifs (Central Alps): from Lawsonite to kyanite eclogite to granulite retrogression. Schweiz Mineral Petr Mitt 74:87-104

Biino G (1995) Pre-Variscan evolution of the eclogitized mafic rocks from the Helvetic basement of the Central Alps. Eur J Mineral 7:57-70

Böhm CO (1996) Provenance and pre-Mesozoic evolution of the Lucomagno unit (Central Swiss Alps): a geochemical, isotopic and geochronological approach, Dissertation, ETH Zürich

Bollin R (1994) Metamorphe Entwicklung und Ursprung der Paragneise (Biotitplagioklasgneise, Plagioklasknotengneise) der Silvretta. Dissertation, Fribourg $180 \mathrm{pp}$

Boriani A, Giobbi Origoni E, Del Moro A (1981) Composition, level of intrusion and age of the "Serie dei Laghi" orthogneisses (northern Italy-Ticino, Switzerland). Rend Soc Ital Min Petrol 38:191-205

Bossart PJ, Meier M, Oberli F, Steiger RH (1986) Morphology versus $\mathrm{U}-\mathrm{Pb}$ systematics in zircon: a high resolution isotopic study of zircon population from a Variscan dike in the Central Alps. Earth Planet Sci Lett 78:339-354

Brown M (1995) The late-Precambrian geodynamic evolution of the Armorican segment of the Cadomian belt (France): distortion of an active continental margin during south-west directed convergence and subduction of a bathymetric high. Géol France 3:3-22

Buschmann B, Linnemann U, Schneider J, Süss T (1995) Die cadomische Entwicklung im Untergrund der Torgau-Doberluger Synklinale. Z Geol Wiss 23:729-749

Bussy F, Raumer J von (1994) U-Pb geochronology of Palaeozoic magmatic events in the Mont-Blanc Crystalline Massif, Western Alps. Schweiz Mineral Petrol Mitt 74:514515

Bussy F, Derron MH, Jaquod J, Sartori M, Thélin P (1996) The 500 Ma-old Thyon metagranite: a new A-type granite occurrence in the Western Penninic Alps (Wallis, Switzerland). Eur J Mineral 8:565-575

Carmignani L, Carosi R, Pisa A di, Gattiglio M, Musumeci G, Oggiano G, Pertusati PC (1994) The hercynian chain in Sardinia (Italy). Geodinam Acta 7:31-47

Chen F, Hegner E, Todt W (2000) Zircon ages and Nd isotopic and chemical compositions of orthogneisses from the Black Forest, Germany: evidence for a Cambrian magmatic arc. Int J Earth Sci 88:791-802

Christiansen JL, Stouge S (1999) Oceanic circulation as an element in palaeogeographical reconstruction: the Arenig (early Ordovician) as an exeample. Terra Nova 11:73-78

Cocks LRM (2000) The Early Palaeozoic geography of Europe. J Geol Soc Lond 157:1-10

Cogné J, Wright AE (1980) L'orogène cadomien. Int Geol Congr 26 Sess C6:29-54

Courjault-Radé P, Debrenne F, Gandin A (1992) Palaeogeographic and geodynamic evolution of the Gondwana continental margins during the Cambrian. Terra Nova 4:657-667
Crowley QG, Floyd PA, Stodra V, Winchester JA, Holland JG (2000) The Marianske-Lazne Complex: remnants of a subducted early Palaeozoic seaway. In: Variscan-Appalachian dynamics: the building of the Upper Palaeozoic basement. Basement Tectonics 15:86-89

Dallmeyer RD, Neubauer F (1994) Cadomian 40Ar/39 Ar apparent age spectra of detrital muscovites from the Eastern Alps. J Geol Soc Lond 151:591-598

Dallmeyer RD, Franke W, Weber K (eds) (1995) Pre-Permian geology of central and eastern Europe. Springer, Berlin Heidelberg New York

Dallmeyer RD, Neubauer F, Fritz H, Mocanu V (1996a) Variscan vs Alpine tectonothermal evolution of the Southern Carpathian orogen: constraints from 40Ar/39Ar ages. Tectonophysics 290:111-135

Dallmeyer RD, Neubauer F, Fritz H, Müller W, Pana D, Putis M (1996b) Tectonothermal evolution of the internal Alps and Carpathians: evidence from 40Ar/39 $\mathrm{Ar}$ mineral and whole-rock data. Eclog Geol Helv 89:203-227

Dalziel WD (1992) On the organization of American plates in the Neoproterozoic and the breakout of Laurentia. Geol Soc Am Today 2:237-241

Desmons J, Compagnoni R, Cortesogno L, Frey M, Gaggero L (1999) Pre-Alpine metamorphism of the Internal zones of the Western Alps. Schweiz Mineral Petr Mitt 79:23-39

Ducrot J, Lancelot JR, Marchand J (1983) Datation U-Pb sur zircons de l'éclogite de la Borie (Haut Allier, France) et conséquences sur l'évolution anté-hercynienne de l'Europe occidentale. Earth Planet Sci Lett 62:385-394

Ebner F, Neubauer F, Stattegger K (1987) The Caledonian event in the Eastern Alps: a review. In: Flügel HW, Grecula P, Sassi FP (eds) Pre-Variscan and Variscan events in the Alpine-Mediterranean mountain belts. Alfa, Bratislava, 169-182 pp

Eichhorn R, Loth G, Höll R, Finger F, Schermaier A, Kennedy A (1999) U-Pb SHRIMP data of pre-alpine rocks of the Tauern Window (Austria): active margin and back-arc found, but where is the adjacent continental crust? Terra Nostra 99:79

Fernández-Suárez J, Gutiérrez-Alonso J, Jenner GA, Jackson SE (1998) Geochronology and geochemistry of the Pola de Allande granitoids (northern Spain): their bearing on the Cadomian-Avalonian evolution of northwest Iberia. Can J Earth Sci 35:1-15

Fernández-Suárez J, Gutiérrez-Alonso J, Jenner GA, Tubrett MN (1999) Crustal sources in Lower Palaeozoic rocks from NW Iberia: insights from laser ablation U-Pb ages of detrital zircons. J Geol Soc Lond 156:1065-1068

Fernández-Suárez J, Gutiérrez-Alonso J, Jenner GA, Tubrett MN (2000) New ideas on the Proterozoic-Early Palaeozoic evolution of NW Iberia: insights from U-Pb detrital zircon ages: Precamb Res 102:185-206

Findlay RH (1997) The Song Ma Anticlinorium, northern Vietnam: the structure of an allochthonous terrane containing an early Palaeozoic island arc sequence. J Asian Earth Sci 15:453-464

Finger F, Quadt A von, Pin C, Steyrer HP (1998) The ophiolite chain along the western Moravo-Silesian plate margin: a trace of the Rheic suture? Acta Univ. Carolinae Geol 42:244-245

Flisch M (1987) Geologische, petrographische und isotopengeologische Untersuchungen an Gesteinen des Silvretta-Kristallins. Dissertation, Univ Bern

Franke W, Altherr R, Haak V, Oncken O, Tanner D (eds) (2000) Orogenic processes: quantification and modelling in the Variscan belt of Central Europe. Geol Soc Lond Spec Publ 179:1-456

Freyer G, Suhr P (1987) Über Archaeocyathinen-Funde und den lithologischen Aufbau des Unterkambriums im Gebiet von Torgau. Z Geol Wiss 15:605-680 
Friedl G, McNaughton N, Fletcher IR, Finger F (1998) New SHRIMP-zircon ages for orthogneisses from the southeastern part of the Bohemian Massif (Lower Austria). Acta Univ Carolinae Geol 42:251-252

Frisch W, Neubauer F (1989) Pre-Alpine terranes and tectonic zoning in the eastern Alps. Geol Soc Am Spec Paper 230:91-100

Gansser A, Pantic N (1988) Prealpine events along the eastern Insubric Line (Tonale Line, northern Italy). Eclog Geol Helv 81:567-577

Gebauer D (1993) The pre-Alpine evolution of the continental crust of the Central Alps: an overview. In: von Raumer J, Neubauer F (eds) The pre-Mesozoic geology in the Alps. Springer, Berlin Heidelberg New York, pp 93-117

Gebauer D, Quadt A, Compston W, Williams IS, Grünenfelder M (1988) Archaean zircons in a retrograded, Caledonian eclogite of the Gotthard Massif (Central Alps, Switzerland). Schweiz Mineral Petrogr Mitt 68:485-490

Girard M, Bussy F (1999) Late Pan-African magmatism in the Himalaya: new geochronological and geochemical data from the Ordovician Tso Morari metagranites (Ladakh, NW India). Schweiz Mineral Petrogr Mitt 79:399-418

Göncüoglu Y, Kozur HW (1999) Palaeozoic stratigraphy and event succession in eastern Toros, Turkey. In: Talent J, Khan F, Mawson R (eds) International Geological Correlation Program IGCP 421: North Gondwana Mid-Palaeozoic bioevent/ biogeography patterns in relation to crustal dynamics, 11-13, North Ryde (Macquarie University Printery)

Gonzalez Cuadra P, Martinez Catalán JR, Arenas R, Diaz Garcia F, Abati J, Dunning GR (1999) Polyorogenic evolution of the uppermost units of the Ordenes Complex (NW Spain). J Conf Abstr11:34

Grunow A, Hanson R, Wilson T (1996) Were aspects of Pan-African deformation linked to Iapetus opening? Geology 24:1063-1066

Guillot F, Liégois JP, Fabre J (1991) Des granophyres du Cambrien terminal dans le Mont Pourri (Vanoise, zone briançonnaise: première datation $\mathrm{U}-\mathrm{Pb}$ sur zircon d'un socle des zones internes des Alpes françaises. CR Acad Sci Paris 313:239-244

Guillot F, Bertrand JM, Pidgeon RT, Leterrier J, Gattiglio M (1998) Géochronologie U-Pb SHRIMP et IDTIMS de zircons des zones internes des Alpes occidentales. 17e RST98 Brest Abstract Volume, p 124

Gurnis M, Torsvik TH (1994) Rapid drift of large continents during the late Precambrian and Palaeozoic: palaeomagnetic constraints and dynamic models. Geology 22:1023-1026

Hammerschmidt K (1981) Isotopengeologische Untersuchungen am Augengneis vom Typ Campo Tures bei Rain in Taufers, Südtirol. Mem Ist Geol Min Univ Padova 34:273-300

Hamoumi N (1999) Upper Ordovician glaciation spreading and its sediumentary record in Moroccan North Gondwana margin. Acta Univ Carolinae Geol 43:111-114

Handler R, Dallmeyer RD, Neubauer F (1997) 40Ar/39Ar ages of detrital white mica from Upper Austroalpine units in the Eastern Alps, Austria: evidence for Cadomian and contrasting Variscan sources. Geol Rundsch 86:69-80

Handy M, Franz L, Heller F, Janott B, Zurbriggen R (1999) Multistage accretion and exhumation of the continental crust (Ivrea crustal section, Italy and Switzerland). Tectonics 18:1154-1177

Hanel M, Montenari M, Kalt A (1999) Determining sedimentation ages of high-grade metamorphic gneisses by their palynological record: a case study in the northern Schwarzwald (Variscan Belt, Germany). Int J Earth Sci 88:49-59

Harper DAT, MacNiocaill CM, Williams SH (1996) The palaeogeography of early Ordovician Iapetus terranes: an integration of faunal and palaeomagnetic constraints. Palaeogeogr Palaeoclimatol Palaeoecol 121:297-312

Haydoutov I (1989) Precambrian ophiolites, Cambrian island arc, and Variscan suture in the South Carpathian-Balkan region. Geology 17:905-908
Hegner E, Kröner A (2000) Review of Nd isotopic data and xenocrystic and detrital zircon ages from the pre-Variscan basement in the eastern Bohemian Massif: speculation on palinspastic reconstructions Geol Soc Lond Spec Publ 179:113-130

Hoffman PF (1991) Did the breakout of Laurentia turn Gondwanaland inside-out? Science 252:1409-1412

Hoinkes G, Thöni M, Lichem C, Bernhard F, Kaindl R, Schweigl J, Tropper P, Cosca M (1997) Metagranitoids and associated metasediments as indicators for the pre-Alpine magmatic and metamorphic evolution of the western Austroalpine Ötztal Basement (Kaunertal, Tirol). Schweiz Mineral Petr Mitt 77:299-314

Hubich D, Loeschke J (1993) Der Comelico-Porphyroid der westlichen Karnischen Alpen (ÖsterreichItalien): Stratigraphie, Petrographie, Geochemie und Zirkonmorphologie. Jahrb Geol BA 136:351-374

Huff WD, Bergström SM, Kolata DR, Cingolani CR, Astini RA (1998) Ordovician K-bentonites in the Argentine Precordillera: relations to Gondwana margin evolution. Geol Soc Lond Spec Publ 142:107-126

Keppie JD (ed) (1994) Pre-Mesozoic geology in France. Springer, Berlin Heidelberg New York

Keppie JD, Dostal J, Murphy JB, Cousens BL (1997) Palaeozoic within-plate volcanic rocks in Nova Scotia (Canada) reinterpreted: isotopic constraints on magmatic source and palaeocontinental reconstruction. Geol Mag 134:425-447

Kleinschrodt R, Gayk T (1999) Analogies and synchronism in the exhumation of HP units in the Variscan orogen: a comparision of the Münchberg Complex and Cabo Ortegal Complex. Terra Nostra 99:119

Klootwijk C (1996) Phanerozoic configurations of Greater Australia: evolution of the North West Shelf. Canberra Australian Geological Survey Organisation

Klötzli-Chovanetz E, Klötzli U, Koller F (1997) Lower Ordovician migmatisation in the Otztal crystalline basement (Eastern Alps, Austria): linking $\mathrm{U}-\mathrm{Pb}$ and $\mathrm{Pb}-\mathrm{Pb}$ dating with zircon morphology. Schweiz Mineral Petr Mitt 77:315-324

Köppel V, Günthert A, Grünenfelder M (1981) Patterns U-Pb zircon and monazite ages in polymetamorphic units of the Swiss central alps. Schweiz Mineral Petr Mitt 61:97-119

Kozur H (1984a) Some new stratigraphical and paleogeographical data in the Paleozoic and Mesozoic of the Pannonian Median Massif and adjacent areas. Acta Geodaetica Geophys Montan Hungar 19:93-106

Kozur H (1984b) New biostratigraphic data from the Bükk-, Uppony- and Mecsek Mountains and their tectonic implications. Acta Geol Hungar 27:307-319

Kröner A, Hegner E (1998) Geochemistry, single zircon ages and $\mathrm{Sm}-\mathrm{Nd}$ systematics of granitoid rocks from the GorySowie (Owl Mts), Polish West Sudetes: evidence for Early Palaeozoic are-related plutonism. J Geol Soc Lond 155:711-724

Kröner A, Willner AP (1998) Time of formation and peak of Variscan HP-HT metamorphism of quartz-feldspar rocks in the central Erzgebirge, Saxony, Germany. Contrib Mineral Petrol 132:1-20

Kröner A, Stipská P, Schulmann K, Jaeckel P (2000) Chronological constraints on the pre-Variscan evolution of the northeastern margin of the Bohemian Massif, Czech Republik. In: Franke W, Altherr R, Haak V, Oncken O, Tanner D (eds) Orogenic processes: quantification and modelling in the Variscan belt of Central Europe. Geol Soc Lond Spec Publ 179:175-198

Laumonier B (1998) Les Pyrénées centrales et orientales au début du Paléozoïque (Cambrien s.l.): évolution paléogéographique et géodynamique. Geodin Acta 11:1-11

Liebetrau V (1996) Petrographie, Geochemie und Datierung der "Flüelagranitischen Assoziation" (sog. Jüngere Orthogneise) des Silvretakristallins Graubünden - Schweiz. Dissertation, Fribourg, 233 pp 
Liebetrau V, Nägler T (1994) Geochronologische und geochemische Diskussion der sogenannten "flüealgranitischen Assoziation" des Silvrettakristallins (Graubünden/Schweiz). Schweiz Mineral Petr Mitt 74:265-268

Liñan E, Quesada C (1990) Rift phase (Cambrian). In: Dallmeyer RD, Martinez Garcia E (eds) Pre-Mesozoic geology of Iberia. Springer, Berlin Heidelberg New York, pp 259266

Linnemann U (1999) The geotectonic setting of the Ordovician of the Saxo-Thuringian Terrane (Central European Variscides, Germany). Acta Univ Carolinae Geol 43:97-99

Linnemann U, Buschmann B (1995) Die cadomische Diskordanz im Saxothuringikum (oberkambrisch-tremadocische overlapSequenzen). Z Geol Wiss 23:707-727

Linnemann U, Gehmlich M, Tichomirova M, Buschmann B (1998a) Introduction to the pre-Symposium excursion: the peri-Gondwanan basement of the Saxothuringian composite terrane. Schr Staatl Mus Min Geol Dresden 9:7-13

Linnemann U, Gehmlich M, Tichomirova M, Buschmann B, Bombach K (1998b) Tectonostratigraphic events of the PeriGondwanan basement of the Saxo-Thuringian composite terrane (Central European Variscides). Schr Staatl Mus Min Geol Dresden 9:159-161

Linnemann U, Gehmlich M, Tichomirova M, Buschmann B, Bombach K (1999) The reflection of orogenic processes within the neoproterozoic to lower Carboniferous sedimentary record of the Saxothuringian terrane. Part I. Cadomian basement to Silurian). Terra Nostra 99:138

Linnemann U, Gehmlich M, Tichomirova M, Buschmann B, Nasdala L, Jonas P, Lützner H, Bombach K (2000) From Cadomian subduction to Early Palaeozoic rifting: the evolution of the Saxo-Thuringian terrane at the margin of Gondwana in the light of single zircon geochronology (Central European Variscides, Germany). Geol Soc Lond Spec Publ 179:131-154

Loeschke J, Heinisch H (1993) Palaeozoic volcanism of the Eastern Alps and its palaeotectonic significance. In: von Raumer J, and Neubauer F (eds), The pre-Mesozoic geology in the Alps. Springer, Berlin Heidelberg New York, pp $441-455$

Lombardo B, Colombo F, Compagnoni R, Ghiglione G, Rubatto D (1997) Relics of pre-Variscan events in the Malinvern-Argentera Complex, Argentera Massif, Western Alps. Third Workshop on Alpine Geological Studies. Quad Geodin Milano 4:66

Loth G, Eichhorn R, Schauder P, Höll R, Kennedy A (1999) U-Pb SHRIMP data from the Wildschönau ophiolite complex: evidence for Cambro-Ordovician rifting in the Western Greywacke supergroup (Eastern Alps). Ber Dt Min Ges Eur J Mineral 11 (Beih):149

MacNiocaill C, van der Pluijm BA, van der Voo R (1997) Ordovician paleogeography and the evolution of the Japetus ocean. Geology 25:159-162

Maniar PD, Piccoli PM (1989) Tectonic discrimination of granitoids. Bull Geol Soc Am 101:635-643

Matte P (1986) Tectonics and plate tectonics model for the Variscan belt of Europe. Tectonophysics 126:329-374

McKerrow WS, Scotese CR, Brasier MD (1992) Early Cambrian continental reconstructions. J Geol Soc Lond 149:599-606

Mélou M, Oulebsir L, Paris F (1999) Brachiopodes et chitinozoaires ordoviciens dans le NE du Sahara Algérien: implications stratigraphiques et paléogéographiques. Geobios 32:823-839

Meng Q-R, Zhang G-W (1999) Timing of collision of the north and south China blocks: controversy and reconciliation. Geology 27:123-126

Ménot RP (1987) Magmatismes paleozoiques et structuration carbonifere du Massif de Belledonne (Alpes Françaises). Mém et Doc Centre Armoricain Etudes Structurales des Socles, vol 21, Rennes, 465 pp
Ménot RP, Peucat JJ, Scarenzi D, Piboule M (1988) 496 My age of plagiogranites in the Chamrousse ophiolite complex (external crystalline massifs in the French Alps): evidence of a lower Paleozoic oceanization. Earth Planet Sci Lett 88:8292

Mingram B (1996) Geochemische Signaturen der Metasedimente des erzgebirgischen Krustenstapels. GeoForschungsZentrum Potsdam Scientific Technical Report STR96/04:1-104

Mingram B (1998) The Erzgebirge a subducted part of Northern Gondwana: geochemical evidence for repetition of early Palaeozoic metasedimentary sequences in metamorphic thrust units. Geol Mag 135:785-801

Mingram B, Rötzler K (1999) Geochemische, petrologische und geochronologische Untersuchungen im ErzgebirgskristallinRekonstruktion eines Deckenstapels. Schriftenr Geowiss 9:1-80

Mingram B, Rötzler K, Tichomirova M, Haase G, Teufel S (1998) Early Palaeozoic rift-related magmatism and passive margin sediments preserved in HP units of the Erzgebirge. Terra Nostra 98:105-107

Montero P, Salman K, Bea F, Azor A, Expósito Ramos I, Gonzáles Lodeiro F, Martinez-Poyatos D, Simancas JF (2000) New data on the geochronology of the Ossa-Morena zone, Iberian Massif. Basement Tectonics 15:136-138

Müller B, Klötzli U, Schaltegger U, Flisch M (1996) Early Cambrian oceanic plagiogranite in the Silvretta nappe. Eastern Alps: geochemical, zircon $\mathrm{U}-\mathrm{Pb}$ and $\mathrm{Rb}-\mathrm{Sr}$ data from garnet-hornblende-plagioclase gneisses. Geol Rundsch 85:822-831

Murphy JB, Nance RD (1989) Model for the evolution of the Avalonian-Cadomian belt. Geology 17:735-738

Nance R, Murphy JB (1994) Contrasting basement isotopic signatures and the palinspastic restoration of periphal orogens: example from the Neoproterozoic Avalonian-Cadomian belt. Geology 22:617-620

Nance RD, Murphy JB (1996) Basement isotopic signatures and Neoproterozoic palaeogeography of Avalonian-Cadomian and related terranes in the circum-North Atlantic. In: Nance RD, Thompson MD (eds) Avalonian and related peri-Gondwanan terranes of the Circum-North Atlantic. Geol Soc Am Spec Pap 304:333-346

Navidad M, Carreras J (1995) Pre-Hercynian magmatism in the Eastern Pyrenees (Cap de Creus and Albera massifs) and its geodynamical setting. Geol Mifnb 74:65-77

Neubauer F (1991) Late Proterozoic and Early Palaeozoic tectonothermal evolution of the Eastern Alps. In: Dallmeyer RD, Lecorché JP (eds) The west African orogens and circum-Atlantic correlatives. Springer, Berlin Heidelberg New York, pp 307-314

Neubauer F, Raumer J von (1993) The Alpine basement: linkage between Variscides and East-Mediterranean mountain belt. In: von Raumer JF, Neubauer F (eds) The pre-Mesozoic geology in the Alps. Springer, Berlin Heidelberg New York, p 641-663

Neubauer F, Sassi FP (1993) The Austroaalpine quartzphyllites and related Palaeozoic formations. In: von Raumer J, Neubauer F (eds) The pre-Mesozoic geology in the Alps. Springer, Berlin Heidelberg New York, pp 423-439

Neubauer F, Hoinkes G, Sassi FP, Handler R, Höck V, Koller F, Frank W (1999) Pre-Alpine metamorphism of the Eastern Alps. Schweiz Mineral Petr Mitt 79:41-62

Noblet C, Lefort JP (1990) Sedimentological evidence for a limited separation between Armorica and Gondwana during the Early Ordovician. Geology 18:303-306

Nussbaum C, Marquer D, Biino G (1998) Two subduction events in a polycyclic basement: Alpine and pre-Alpine highpressure metamorphism in the Suretta nappe, Swiss Eastern Alps. J Metam Geol 16:591-605

Oberli F, Meier M, Biino G (1994) Time constraints on the preVariscan magmatic/metamorphic evolution of the Gotthard and Tavetsch units derived from single-zircon $\mathrm{U}-\mathrm{Pb}$ results. Schweiz Mineral Petrogr Mitt 74:483-488 
O’Brien PJ, Kröner A (1999) Zircon ages of meta-eclogites in the Monotonous series of the Moldanubian zone in Austria and their significance. Ber Dtsch Min Ges Eur J Mineral 11 (Beih): 170

O'Brien PJ, Duyster J, Grauert B, Schreyer W, Stöckhert B, Weber K (1997) Crustal evolution of the KTB drill site: from oldest relics to the late Hercynian granites. J Geophys Res 102:18203-18220

Oliver GJH, Corfu F, Krogh TE (1993) U-Pb ages from SW Poland: evidence for a Caledonian suture zone between Baltica and Gondwana. J Geol Soc Lond 150:355-369

Oncken O (1997) Transformation of a magmatic arc and an orogenic root during oblique collision and its consequences for the evolution of the European Variscides (Mid-German Crystalline rise). Geol Rundsch 86:2-20

Özmen F, Reischmann T (1999) The age of the Sakarya continent in West Anatolia: implication for the evolution of the Aegean region. J Conf Abstr 4:805-806

Ordoñez Casado B (1998) Geochronological studies of the preMesozoic basement of the Iberian Massif: the Ossa Morena zone and the Allochthonous Complexes within the Central Iberian zone. Dissertation ETH no. 12.940, 235 pp

Panwitz C, Handler R, Heinisch H, Neubauer F (2000) ${ }^{40} \mathrm{Ar} /$ ${ }^{39}$ Ar-dating on detrital white micas from Austroalpine Palaeozoic of Northern Greywacke Zone (Tyrol/Salzburg-Austria): a pilot study. Terra Nostra 2000:83

Paquette JL, Ménot RP, Peucat JJ (1989) REE, Sm-Nd and $\mathrm{U}-\mathrm{Pb}$ zircon study of eclogites from the Alpine External massifs (Western Alps): evidence for crustal contamination. Earth Planet Sci Lett 96:181-198

Paris F (1993) Evolution paléogéographique de l'Europe au Paléozoïque inférieur: le test des Chitinozoaires. CR Acad Sci Paris 316:273-280

Paris F, Robardet M (1990) Early Palaeozoic palaeobiogeography of the Variscan regions. Tectonophysics 177:193-213

Paris F, Robardet M, Dabard MP, Ghienne JF, Guillocheau F, Le Hérisse A, Loi A, Mélou M, Feist R, Servais T, Shergold J, Vidal M, Vizcaïno D (1999) Ordovician sedimentary rocks of France. Acta Univ Carolinae Geol 43:85-88

Pearce JA, Nigel B, Harris W, Tindle AG (1984) Trace element discrimination diagrams for the tectonic interpretation of granitic rocks. J Petrol 25:956-983

Pin C (1991) Central Western Europe: major stages of development during Precambrian and Paleozoic times. In: Dallmeyer RD, Lécorché JP (eds) The West African orogens and circum-atlantic correlatives. Springer, Berlin Heidelberg New York, pp 295-306

Pin C, Lancelot J (1982) U-Pb dating of an Early Palaeozoic bimodal magmatism in the French Massif Central and of its further metamorphic evolution. Contrib Mineral Petrol 79:1-12

Pin C, Marini F (1993) Early Ordovician continental break-up in Variscan Europe: $\mathrm{Nd}-\mathrm{Sr}$ isotope and trace element evidence from bimodal igneous associations of the Southern Massif central, France. Lithos 29:177-196

Piper JDA (2000) The Neoproterozoic Supercontinent: Rodinia or Palaeopangea? Earth Planet Sci Lett 176:131-146

Poller U, Nägler TF, Liebetrau V, Galetti G (1997) The Mönchalpgneiss: geochemical characteristics and $\mathrm{Sm}-\mathrm{Nd}$ data of a polymetamorphic S-type granitoid (Silvretta nappe/Switzerland). Eur J Mineral 9:411-422

Powell C, McElhinny MW, Meert JG, Park JK (1993) Palaeomagnetic constraints on timing of the neoproterozoic breakup of Rodinia and the Cambrian formation of Gondwana. Geology 21:889-892

Prigmore JK, Butler AJ, Woodcock NJ (1997) Rifting during separation of Eastern Avalonia from Gondwana. Evidence from subsidence analyses. Geology 25:203-206

Quadt A von (1992) U-Pb zircon and Sm-Nd geochronology of mafic and ultramafic rocks from the central part of the Tauern Window (Eastern Alps). Contrib Mineral Petrol 110:57-67
Quadt A von, Günther D, Frischknecht R, Zimmermann R, Franz G (1997) The evolution of pre-Variscan eclogites of the Tauern Window (Eastern Alps): A Sm/Nd-, conventional and Laser ICP-MS zircon U-Pb study. Schweiz Mineral Petrogr Mitt 77:265-279

Rapela CW, Coira B, Toselli A, Saavedra J (1992) El magmatismo del Paleozoico inferior en el sudoeste de Gonwana. In: Gutierrez-Marco JC, Saavedra J, Rabano J (eds) Paleozoico inferior de Ibero-America, Univ Extremadura, Spain, pp 21-68

Rast N, Skehan JW (1983) The evolution of the Avalonian plate. Tectonophysics 100:257-286

Raumer JF von (1998) The Palaeozoic evolution in the Alps: from Gondwana to Pangea. Geol Rundsch 87:407-435

Raumer J von, Neubauer F (1993a) Late Precambrian and Palaeozoic evolution of the Alpine Basement: an overview. In: von Raumer J, Neubauer F (eds) The pre-Mesozoic geology in the Alps. Springer, Berlin Heidelberg New York, pp 625-639

Raumer J von, Neubauer F (eds) (1993b) The pre-Mesozoic geology in the Alps. Springer, Berlin Heidelberg New York

Raumer J von , Bussy F, Schaltegger U (1999) Ordovician granitoids in the Alps: significance and Peri-Gondwanan correlation. Terra Nostra 99:165

Reischmann T, Anthes G (1996a) Das kristalline Grundgebirge am NW Rand des Rheingrabens. In: Geiger M (ed) Haardt und Weinstrasse: Beiträge zur Landeskunde. Veröffentlichungen der pfälzischen Gesellschaft zur Förderung der Wissenschaften, Speyer, pp 36-59

Reischmann T, Anthes G (1996b) Geochronology of the midGerman crystalline rise west of the River Rhine. Geol Rundsch 85:761-774

Reitz E, Höll R (1991) Biostratigraphischer Nachweis von Arenig in der nördlichen Grauwackenzone. Jahrb Geol BA 134:329-344

Robardet M (1996) Early paleozoic palaeogeography of NorthGondwanan Europe: Serie Correlación Geol 12:167-180

Robardet M, Paris F, Racheboeuf PR (1990) Palaeogeographic evolution of southwestern Europe during Early Palaeozoic times. Geol Soc Am Mem 12:411-419

Robardet M, Verniers J, Feist R, Paris F (1994) Le Paléozoïque de France, contexte paléogéographique et géodynamique. Géol France 3:3-31

Romer R, Franz L (1998) Ordovician Barrow-type metamorphism in the Strona-Ceneri Zone (northern Italy) dated by U-Pb on staurolite. Schweiz Mineral Petr Mitt 78:383-395

Romer RL, Schärer U, Steck A (1996) Alpine and pre-Alpine magmatism in the root-zone of the Western Central Alps. Contrib Mineral Petrol 123:138-158

Santos Zalduegui JF, Schärer U, Gil Ibarguchi JI (1995) Isotope constraints on the age and origin of magmatism and metamorphism in the Malpica-Tuy allochthon, Galicia, NW Spain. Chem Geol 121:91-103

Sassi FP, Neubauer F, Mazzoli C, Sassi R, Spiess R, Zirpoli G (1994) A tentative comparison of the Palaeozoic evolution of the Austroalpine and Southalpine quartzphyllites in the Eastern Alps. Per Mineral 63:35-52

Schaltegger U (1992) Die polymetamorphe Geschichte des Aarmassivs: neue U/Pb-Resultate. Schweiz Mineral Petr Mitt $72: 148-149$

Schaltegger U (1993) The evolution of the polymetamorphic basement in the central Alps unravelled by precise $\mathrm{U}-\mathrm{Pb}$ zircon dating. Contrib Mineral Petrol 113:466-478

Schaltegger U, Gebauer D (1999) Pre-Alpine geochronology of the Central, Western and Southern Alps. Schweiz Mineral Petrogr Mitt 79:79-87

Schaltegger U, Nägler T N, Corfu F, Maggetti M, Galetti G, Stosch H (1997) A Cambrian island arc in the Silvretta nappe: constraints from geochemistry and geochronology. Schweiz Mineral Petrogr Mitt 77:337-350 
Schätz M, Bachtadse V, Tait JA, Soffel HC (1997) Palaeomagnetic results from Lower Devonian sediments of the Southern Alps. Terra Nostra 97:152-155

Schermaier A, Schindlmayr A, Finger F, Roberts M, Pin C (1998) Evidence for Early Palaeozoic subduction and arccontinent collision in the Oetztal-Silvretta crystalline basement (Western Eastern Aps). Acta Univ Carolinae Geol 42:330-331

Schindlmayr A (1999) Granitoids and plutonic evolution of theÖtztal-Stubai Massif. Dissertation, Univ Salzburg, $287 \mathrm{pp}$

Schmidt K (1977) Der altpaläozoische Magmatismus und seine Stellung in der tektonischen Geschichte Mittel- und Südwesteuropas. Z Dtsch Geol Ges 128:121-141

Schönlaub HP (1993) Stratigraphy, biogeography and climatic relationships of the Alpine Paleozoic. In: von Raumer J, Neubauer F (eds) The pre-Mesozoic geology in the Alps. Springer, Berlin Heidelberg New York, pp 65-91

Schönlaub HP (1997a) The biogeographic relationship of Ordovician strata and fossils of Austria. Ber Geol Bundesanstalt Wien 40:6-19

Schönlaub HP (1997b) The Silurian of Austria. Ber Geol Bundesanstalt Wien 40:20-41

Schönlaub HP, Heinisch H (1993) The classic fossiliferous palaeozoic units of the eastern and southern alps. In: von Raumer J, Neubauer F (eds) The pre-Mesozoic geology in the Alps. Springer, Berlin Heidelberg New York, pp 395-422

Schönlaub HP, Histon K (2000) The palaeozoic evolution of the Southern Alps. Mitt Österr Geol Ges 92:15-34

Sdzuy K, Liñan E, Gozalo R (1999) The Leonian stage (early Middle Cambrian), a unit for Cambrian correlation in the Mediterranean subprovince. Geol Mag 136:39-48

Sengör AMC, Natal'in BA (1996) Palaeotectonic of Asia: fragments of a synthesis. In: Yin A, Harrison M (eds) The tectonic evolution of Asia. Cambridge University Press, Cambridge, pp 486-640

Sergeev SA, Steiger RH (1993) High-precision U-Pb single zircon dating of Variscan and Caledonian magmatic cycles in the Gotthard massif, Central Swiss Alps. Terra Nova Abstr 5:394-395

Skehan JW, Rast N (1983) Relationship between Precambrian and lower Palaeozoic rocks of southeastern New England and other north Atlantic Avalonian terranes. In: Schenk PE (ed) Regional trends in the geology of the Appalachian-Caledonian-Hercynian-Mauritanide orogen. Mathematical and physical sciences. Reidel, Dordrecht, pp 131-162

Söllner F, Höll R, Miller H (1991) U-Pb Systematik der Zirkone in Metavulkaniten ("Porphyroiden") aus der nördlichen Grauwackenzone und dem Tauernfenster (Ostalpen, Österreich). Z Dtsch Geol Ges 142:285-299

Stampfli G (1996) The intra-Alpine terrain: a palaeotethyan remnant in the Alpine Variscides. Eclog Geol Helv 89:12-42

Stampfli G (2000) Tethyan oceans. In: Boxkurt E, Winchester JA, Piper JD (eds) Tectonics and magmatism in Turkey and the surrounding area. Geol Soc Lond Spec Publ 173:1-23

Stampfli G M, Mosar J (1996) Palaeozoic evolution of the Tethyan domain. 14. Schweiz Tektonikertreffen, abstract vol:34

Stampfli G, Marcoux J, Baud A (1991) Tethyan margins in space and time. Palaeogeogr Palaeoclimatol Palaeoecol 87:373-409

Stille P, Tatsumoto M (1985) Precambrian tholeiitic-dacitic rocksuites and Cambrian ultramafic rocks in the Pennine nappe system of the Alps: evidence from $\mathrm{Sm}-\mathrm{Nd}$ isotopes and rare earth elements. Contrib Mineral Petrol 89:184-192

Stipska P, Schulmann K, Kroener A (1998) Role of Cambro-Ordovician rifting in Variscan collision at the NE margin of the Bohemian Massif. Acta Univ Carolinae Geol 42:343-344

Tait J, Schätz M, Bachtadse V, Soffel H (1998) Paleogeography of paleozoic terranes in the Varican and Alpine fold belts. Schr Staatl Mus Min Geol Dresden 9:192-193

Tessensohn F (1999) Alpine-type orogens at the Palaeo-Pacific margin of Gondwana: the lack of Wilson cycles. Terra Nostra 99:198-199
Thélin P, Sartori M, Burri M, Gouffon Y, Chessex R (1993) The pre-Alpine basement of the Briançonnais (Wallis, Switzerland). In: von Raumer J, Neubauer F (eds) The pre-Mesozoic geology in the Alps. Springer, Berlin Heidelberg New York, pp 297-315

Thöni M (1999) A review of geochronological data from the Eastern Alps. Schweiz Mineral Petrogr Mitt 79:209-230

Torsvik H, Eide EA (1998) Phanerozoic paleogeography and geodynamics with Atlantic details. NGU report, p 82

Torsvik TH, Smethurst MA (1994) Geographic mapping and paleoreconstruction package (GMAP). Software description and examples of paleoreconstructions

Torsvik TH, Smethurst MA (1996) Continental break-up and collision in the Neoproterozic and Palaeozoic: a tale of Baltica and Laurentia. Earth Sci Rev 40:229-258

Torsvik TH, Smethurst MA (1999) Plate tectonic modelling: virtual reality with GMAP. Comput Geosci 25:395-402

Torsvik TH, Trench A, McKerrow WS (1994) Implications of paleomagnetic data from the Tortwoth Silurian inlier (southern Britain) to paleogeography and Variscan tectonism. Geophys J Int 119:91-100

Tremblay A, Laflèche MR, McNutt RH, Bergeron M (1994) Petrogenesis of Cambro-Ordovician subduction-related granitic magmas of the Quebec Appalachians, Canada. Chem Geol 113:205-220

Ugidos JM, Valladares MI, Recio C, Rogers G, Fallick AE, Stephens WE (1997) Provenance of Upper PrecambrianLower Cambrian shales in the Central Iberian Zone, Spain: evidence from a chemical and isotopic study. Chem Geol 136:55-70

Unrug R (1997) Rodinia to Gondwana: the geodynamic map of Gondwana supercontinent assembly. Geol Soc Am Today $7: 1-6$

Unrug R, Haranczyk C, Chosyk-Jaminska M (1999) Easternmost Avalonian and Armorican-Cadomian terranes of central Europe and Caldeonian-Variscan evolution of the polydeformed Krakóv mobile belt: geological constraints. Tectonophysics 302:133-157

Üstaömer PA (1999) Pre-Early Ordovician Cadomian arc-type granitoids, the Bolu Massif, West Pontides, northern Turkey: geochemical evidence. Int J Earth Sci 88:2-12

Valverde-Vaquero P, Dunning GR (2000) New U-Pb ages for Early Ordovician magmatism in Central Spain. J Geol Soc Lond 157:15-26

Van der Voo R (1993) Paleomagnetism of the Atlantic, Tethys and Iapetus oceans. Cambridge University Press, Cambridge

Van Staal CR, Dewey JF, Niocaill CM, Mckerrow WS (1998) The Cambrian-Silurian tectonic evolution of the Northern Appalachians and British Caledonides: history of a complex, west and southwest Pacific-type segment of Iapetus. In: Blundell DJ, Scott AC (eds) Lyell: the past is the key to the present. Geol Soc Lond Spec Publ 143:199-242

Weger M, Loth G, Höll R, Masch L, Köhler H, Rohrmüller J (1999) Cambrian sedimentation, Ordovician and Devonian subduction, collision and uplift in the southern ZEV (Zone of Erbendorf-Vohenstrauss, Western margin of Bohemian Massif). Terra Nostra 99:207

Winchester JA, Floyd PA, Franke W, Zelazniewicz A, Patocka F, Kryza R, Cymerman Z, Piaseck MAJ, Seston R, Crowley QG, Kachlik V, Stedra V, Holland JG (1998) A review of recent geochemical and structural evidence for major Palaeozoic rifting and re-assembly within the Bohemian Massif. Acta Univ Carolinae Geol 42:359-360

Williams KE (1997) Early Palaeozoic palaeogeography of Laurentia and western Gondwana: evidence from tectonic subsidence analysis. Geology 25:747-750

Wirsing A (1997) Die Orthogneise des oberen Val Bérard (Aiguilles-Rouges-Massiv, Westalpen, Frankreich). Dissertation, Univ Fribourg 
Yin A, Nie S (1996) A Phanerozoic palinspastic reconstruction of China and its neighboring regions. In: Yin A, Harrison M (eds) The tectonic evolution of Asia. Cambridge Univ Press, Cambridge, pp 442-485

Zeh A, Brätz H, Cosca M, Tichomirova M, Okrusch M (1997\} $39 \mathrm{Ar} / 40 \mathrm{Ar}$ und $207 \mathrm{~Pb} / 206 \mathrm{~Pb}$ Datierungen im Ruhlaer Kristallin, Mitteldeutsche Kristallinzone. Terra Nostra 97:212-215

Ziegler P (1984) Caledonian and Hercynian crustal consolidation of western and central Europe: a working hypothesis. Geol Mijnb 63:93-108

Zingg MA (1989) Die Siviez-Mischabel-Decke: Entstehung und Entwicklung eines Altkristallins. Schweiz Mineral Petrogr Mitt 69:130
Zonenshain LP, Kuzmin MI, Kononov MV (1985) Absolute reconstructions of the Paleozoic oceans. Earth Planet Sci Lett 109:103-116

Zulauf G, Schitter F, Riegler G, Finger F, Fiala J, Vejnar Z (1999) Age constraints on the Cadomian evolution of the Teplá Barrandian unit (Bohemian Massif) through electron microprobe dating of metamorphic monazite. Z Dtsch Geol Ges 150:627-639

Zurbriggen R, Franz L, Handy M (1997) Pre-Variscan deformation, metamorphism and magmatism in the Strona-Ceneri Zone (southern Alps of northern Italy and southern Switzerland). Schweiz Mineral Petrogr Mitt 77:361-381

Zwart HJ, Dornsiepen UF (1978) The tectonic framework of Central and Western Europe. Geol Mijnb 57:627-654 